Article

\title{
Determinants of the Public Debt in the Eurozone and Its Sustainability Amid the Covid-19 Pandemic
}

\author{
Hernán Ricardo Briceño * and Javier Perote $\mathbb{}$ \\ Department of Economics and Economic History and Instituto Multidisciplinar de Empresa (IME), \\ Campus Miguel de Unamuno (F.E.S. Building), University of Salamanca, 37007 Salamanca, Spain; \\ perote@usal.es \\ * Correspondence: hrbriceno@usal.es
}

Received: 26 June 2020; Accepted: 4 August 2020; Published: 11 August 2020

\begin{abstract}
Different economic studies have been concentrated on specific and/or isolated factors to explain public debt evolution. In this article we have developed an integrated viewpoint based on financial, social and governance or institutional factors. Under our dynamic econometric assessment for the last two decades (i.e., since the Euro currency inception), economic growth, interest rate, life expectancy at birth, unemployment, government effectiveness and the last sovereign debt crisis have resulted as being the major determinants of its evolution. Public debt sustainability must be assessed continuously with the aim to discuss technical recommendations to maintain it at an even rate, to allow sustainable economic growth and better life standards, in the context of life expectancy increasing and stable governance and institutional conditions. Undoubtedly, the Covid-19 pandemic leads more damaged Eurozone countries with negative real economic growth and high unemployment rates to increase dramatically their current public debts, to such an extent that they could fall into unsustainable paths. Therefore, substantial reforms in European pension and unemployment insurance systems are necessary conditions to ensure public debt sustainability amid Covid-19 pandemic.
\end{abstract}

Keywords: sustainability; public debt; Covid-19 pandemic; governance-institution indicators; Eurozone

\section{Introduction}

Currently, public debt issues have become again a major academic, policy-maker and journalist topic of discussion in the Eurozone, which has suffered three major crashes since its conformation, in the last two decades: the subprime mortgage crisis, the sovereign debt crisis and recently the Covid-19 pandemic. Undoubtedly, this current health crisis has generated a brutal stumbling block in the large recovery from the last sovereign debt crisis (2009-2012). The Eurozone economies did not finish recovering from it, and they have to face again high public budget deficits in 2020 and unprecedented growth in public debts derived from the pandemic, the obligatory two-three months of quarantine, social immobilization, closing borders, reduction of international commerce and huge unemployment rates. Indeed, the main aim of this working research paper is to identify the determinant factors of the public debt, in order to assess to what extent these factors can influence their sustainability amid the Covid-19 pandemic.

Different developing countries have been receiving financial support and resources from the World Bank and the International Monetary Fund; furthermore, the G20 group of most developed economies have decided not to charge the poorest countries, but it is a little impossible to get these kinds of facilities for European countries. However, in the middle of different policy proposals, meetings and discussions, the European Union has approved the establishment of a fund of $€ 100$ billion, which was required by the Spanish government and others with the aim to support especially the cost of firing workers and 
unemployment insurance, as the ERTE by starting the quarantine. The ERTE (Expediente de Regulación Temporal de Empleo) is a Spanish temporary unemployment subsidy for workers who were temporary unemployed because of the economic activity stoppages caused by the Covid-19 pandemic.

The most recently damaged countries-Spain, Italy and France-amid the pandemic have seen highly increased their public debts in the first half-year of the Covid-19 health crisis. Spanish public debt, having reached $99 \%$ of the GDP in 2019, increased $€ 35.4$ billion in the first quarter, meeting $€ 27.6$ miles per capita. Italy reached a public deficit of $10.4 \%$, and its public debt ratio was around $156 \%$ of the GDP. France, after having public debt ratios below $100 \%$ since adoption of the Euro, surpassed above $101 \%$, in the first quarter of 2020. These statistics are associated with the dramatic GDP contraction for 2020, with $-12.8 \%$ for Spain and Italy, and $-12.5 \%$ for France. These rates are above the average for Eurozone projections [1].

In this way, since starting negotiations to get financial support, Spain and Italy were proposed the mutualization of their new public debts emissions to deal with the high cost of the pandemic. Additionally, the European Central Bank proposed the creation of a reconstruction fund to buy public debt from troubled countries derived from pandemic, but conditionality on accepting public policy implementations to guarantee the economic growth. However, initially North European countries and the so-called frugal countries (Holland, Austria, Denmark and Sweden) were opposed to these proposals - they proposed supporting only with soft credits. It is also fair to point out that the fiscal deficit for the first quarter of 2020 is not only in European countries, but also in different countries. For instance, the United States of America is expected to reach a federal budget deficit of US $\$ 3.7$ trillion by the end of 2020. Japan's public debt ratio is supposed to reach about 240\% of the GDP between 2020-2021.

Therefore, the central research question of this paper focuses on analyzing what are the main factors that have determined the public debt evolution of the Eurozone countries, after the Euro currency introduction (1999), in the last twenty years. This topic becomes more relevant because of the fact that there is not a fiscal union yet, neither are there homogeneous social policy regulations, such as an employment and pension system. The second research question concerns the assessment that would allow us to declare whether public indebtedness has been adequately managed, according to the evolution of different economic-financial, social and institutional quality factors. This second issue is only preliminary addressed based on the obtained relations and the new economic and social indicators amid the Covid-19 pandemic.

Among the first group we consider the economic growth, interest rate, primary balance of the public sector (government tax collection and spending), etc. In the case of social factors, we are considering the unemployment rates and the expected life at birth of the population, its aging and growth rates, the public health situation for preventing and coping with possible pandemics. The institutional and governance indicators included Voice and Accountability, Government Effectiveness, Corruption Perception and/or Control Corruption, Political Stability, Regulatory Quality, as well as Rule of Law.

Fiscal sustainability is a crucial topic nowadays amid the Covid-19 pandemic, with international financial analysts, investors and investment grading institutions focusing on this issue to assess the capacity of a government to comply or not with its debt and liability commitments-amortization of the principal and payment of interest-to its creditors, which in turn impacts on the sovereign risk score and the cost of public debt for governments. Indeed, among the relevant institutional factors are corruption-related indexes, which have been obtained from Worldwide Governance Indicators (World Bank) and Transparency International, a non-governmental organization (NGO).

This document implicitly and explicitly also sheds a light on the sustainability of European Union public debts, in accordance with these financial, socioeconomic and institutional quality factors that explain their evolution. But how can we explain sustainability of public debt? This question does not have a straightforward answer. In this paper, we approach it by understanding its determinants and estimating a joint model that aims to anticipate the expected impact of the Covid-19 crisis, given the relation in the past for the Eurozone. This would represent a clear warning for policy makers to be serious in containing public debt expansion in the long run. For instance, the current manager 
director of the International Monetary Fund in reference to Argentina said, "it has serious problems because its public debt is unsustainable, in a context that this Latin-American country postpones the restructuration of its debt". Therefore, we can continue with more technical specifications about sustainability of public debt in the Eurozone.

Consequently, after receiving currently enormous rescue packages because of the pandemic, in the next years responsible governments should adopt budget constraints and public policies in order to mitigate the current expansion of their public debts, in accordance with our sustainability assessment. For instance, we are concerned especially with the High Indebted Euro Countries (HIDC) with public debt to GDP ratio above $100 \%$, such as Italy and Spain. Countries that benefit from the mutualized reconstruction fund of $€ 750,000$ million, passed by the Europe Commission by the end of May 2020, which includes structural reform commitments. Corresponding to $€ 500$ billion as cash transferences and $€ 250$ billion as soft borrowings: Italy, Spain, France and Germany were benefiting with $€ 172,745, € 140,446, € 38,772$, and $€ 28,806$ million, respectively. Additionally, the amount of the Pandemic Emergency Purchase Program (PEPP) increased to $€ 600$ billion by June 2020; it was prolonged up to June, 2021.

Last but not least, it is also fair to point out that the Council of the European Union's recovery efforts at the level of the presidents (July 2020) has also approved a mutual fund of $€ 750,000$ million to deal with the adverse socioeconomic effects of the Covid-19 pandemic $-€ 390,000$ million for direct support, the rest for loans. The aim of the fund is to prevent the health of citizens and stoppages of the economy. This happened after a very wide-ranging package was presented at the end of May, 2020 which combined the future Multiannual Financial Framework (MFF) and a specific recovery effort under Next Generation European Union (NGEU). However, this support includes a plan of reforms that the countries must adopt.

In the next section, we review some concepts and ideas about how public debt has been accumulated, what factors have determined it in the last centuries, and its possible sustainability in the Eurozone. This section also describes the evolution of some financial, socioeconomic and institutional variables used for our econometric assessment, which possibly have been determining the public debt as well as its sustainability. Section 3 will focus on the econometric panel data dynamic assessment, through different models and estimation techniques that account for the effects as well as possible endogeneity and multicollinearity problems. The following Section 4, based on our econometric results will be concentrated on the adverse effects discussion amid the Covid-19 pandemic in EU public finance. In the last Section 5, we sum up some conclusions and recommendations to improve the sustainability management of the Euro public debt, especially in the HIDC, in their increasing current context.

\section{Materials and Data}

\subsection{Literature Review}

Different factors can explain the high level of the current public debt reached by some Euro countries in the last two decades; especially, for countries with above $100 \%$ of their own GDP. For instance, in the case of Spain, it could be the sovereign debt crisis (2009-2012), after borrowing $€ 100$ billion in the fourth quarter of 2012. Similarly, this pre-pandemic crisis contributed to Greece, Ireland and Portugal increasing their public debts after being rescued in 2011. Meanwhile, in 2020, the increasing of the public debt has been caused by a Malthus type of prediction triggered by the Covid-19 pandemic, with thousands of deaths, which has forced more damaged countries to strongly increase their public spending on health and prevention systems, to correct current weak aspects in both systems; as well as financing unemployment insurance to assure subsistence means for unemployed workers.

In "An Essay on the Principle of Population", a little more than two centuries and two decades ago, Robert Malthus [2] said that the population increased at a geometric rate, and subsistence for men only at an arithmetic rate. The increase of the human species would evidently be much greater 
than any increase that has been hitherto known. The poorest people consequently must live much worse, and many of them be reduced to severe distress. The number of laborers also being above the proportion of the work in the market, the price of labor must tend toward a decrease, while the price of provisions would at the same time tend to rise. The laborer therefore must work harder to earn the same as he did before.

In this vein, more than two centuries later, Eatock [3] maintains that one in four European citizens currently depends on their pension income, and younger citizens will one day also benefit from pensions. Consequently, the pension system is one of the biggest public expenditure items; in a context of lower birth rates and increasing longevity (expectancy of life at birth), it has come under increasing pressure. Overall European Union spending on public pensions as a percentage of the GDP is now expected to be similar in 2060 to today's level, despite demographic ageing. The population in European Union is ageing due to a combination of increasing longevity and low birth rates. People aged over 65 are becoming a much more significant group, whilst the 15-64 age group is shrinking.

In accordance with these last asseverations, the current General Director of the World Health Organization Tedros Ghebreyesus [4] said (in a press conference on May 2020) that people have improved their standards of living, they nowadays have longer and healthier lives, but economic progress is too slow to achieve the Sustainable Development Goals. Global life expectancy has increased by 5.5 years, from 66.5 to 72 years, in recent years. Spain ranks third in the world, with a life expectancy of 83 years, only behind Japan and Switzerland with 84.2 and 83.3 years, respectively. However, this life expectancy improvement will now be threatened by the Covid-19 pandemic. Consequently, there is a need for all countries to invest in strong health systems, as the best defense against current pandemic outbreaks and other diseases.

Maybe Robert Malthus implicitly said that people will live more years nowadays, but also their personal incomes will be scarce to finance their longevity, because of the fact that in modern society it is expected that people finance their own means of life. Therefore, the natural question is who would pay for these issues as expectancy of life increases, if the personal subsistence resources are poor? Friedman [5] reintroduced the old phrase "there's no such thing as a free lunch" as the title of his book of essays on public policy. This phrase means that our society cannot get improvements without costs, and for each alternative chosen to solve any social problem, there is a best option with an opportunity or alternative cost.

In this way, Cossia [6], concluded that several countries within the European Monetary Union (EMU) have elevated their public debt ratios from 2001, although there is heterogeneous evolution in their public debts, due to different factors: demographic, economic, fiscal or structural. These factors cause asymmetric effects of the economic policies on public debt and growth, concluding that these socioeconomic issues of high public debt in Europe need to be solved with an economic policy of debt dissolution. This means redesigning the socioeconomic environment to eliminate the basic conditions that cause these problems considering the specificities of each countries, thus enabling European society and the involved institutions to do better in the future than the best they can do today. The author concludes that there is a high heterogeneity between countries within and outside the European Monetary Union due to different socioeconomic factors.

Furthermore, the heterogeneity has been also in health expenditure. In accordance with "Health and Glance: Europe 2018" [7], after the sovereign debt crisis (2009-2012), some countries have recovered and other maybe more than improved their health public investment across Europe in the last decade. Across the EU as a whole, health spending per capita increased by around 1.9\% each year in real terms between 2013 and 2017, compared with an annual growth rate of only 0.6\%, between 2009 and 2013 . During this crisis, ten EU countries saw health expenditure retracted in real terms, with only Bulgaria and Romania continuing to grow above $5 \%$ annually. In the subsequent four years there has been a large-scale turnaround, but two EU countries are seeing some growth, despite economic growth having remained slow in some countries. Therefore, health systems need to be more efficient in accordance with demographic (ageing) changes using new digital technology. 
In accordance with demographic ageing, the sustainability problems of the pension system in some European countries have been expected for a long time, but in the last years they have been sharpened. For instance, the deficit in Spain increased to reach $€ 16,6$ billion in 2019. In accordance with the Allianz Pension Report [8], this country has begun since this cumbersome point to reach a sustainable pension system to keep up with the conditions of retired workers being the same to active employee's life conditions. In accordance with the report, Spain placed 67 out of 70 in sustainability conditions, with a compelling structural deficit. The public social spending on third aged people, above $11 \%$ of GDP, has led Spanish public finance to have serious sustainability problems.

Consequently, in order to European governments continue approving to invest on healthcare and pension systems, it should be very important for policymakers to assess the sustainability of public debt. A simple starting point for our sustainability assessment risks relates to the evolution of the (explicit) government debt-to-GDP ratio; as high and rising debt ratios already hint at potential sustainability problems in the government budget constraint, we chose as a central variable the Public debt-to-GDP ratio. This is because high and rising government debt ratios indicate potential sustainability problems (Lojsch et al.) [9].

For other authors, the assessment of public debt sustainability arguably intends to simply answer the question about its correct measure, when the public debt in a country is becoming so big that it would not be fully serviced, tracking its evolution over time (Wyplosz) [10]. Whenever the interest rate exceeds the economy's growth rate, the debt accumulation process is intrinsically unstable, which is precisely why sustainability is an important macroeconomic issue. Two difficulties follow: First, relatively small changes in the real interest and growth rates can tilt the debt path from stability to instability. Second, when the real interest and economic growth rates are close, small shocks can have dramatically powerful effects on the public debt path.

For other authors, the sustainable fiscal policy must respect the present value borrowing constraint under the economic environment, with the intertemporal budget constraint being a necessary condition for sustainability (Collignon) [11]. If debt must not explode over time, policy makers have to respond to the changing conditions in their tax base (economic growth) and to the cost of finance (interest rate) with suitable policies. The author concluded that European public debt is sustainable in this respect. A government can be solvent in the sense that it can raise sufficient revenue in the future to pay the service of public debt.

In accordance with D'Erasmo et al. [12], different strategies of policies can be equivalent to restore fiscal solvency, however, they can have different effects on welfare, macro aggregates and production. This is particularly the case for taxes on capital in the United States and labor taxes in Europe. Furthermore, the fact that both are financially integrated economies implies that the revenue-generating capacity of taxation on capital income is adversely affected by international externalities. A structural change in fiscal accounts has been found since the 2008 international financial crisis.

In this vein, Kudla [13], in his dynamic panel data econometric methodology considers that the set of explanatory variables of the public debt are: (a) variables that affect the directly distinguished factors of spending, the ratio of interest payable, subsides, general government expenditures to the GDP; (b) social conditions of the economy, such as the unemployment rate, ratio of social security expenditure to total government expenditure and population growth; (c) the attractiveness of the economy to foreigners partners, net foreign direct investment (FDI) inflow, the stock of FDI in the economy, the openness factor-(Export + import) /GDP.

Aldama et al. [14], estimated and compared different specifications of fiscal rules for the United States of American Public debt, with the aim to test its sustainability in the long run using annual data. On the one hand, with Standard Model-Based Sustainability (MBS) analysis they concluded that estimates of constant-parameter fiscal rules showed no evidence of sustainability, maybe due to instability of government behavior over time. However, the estimated Markov-switching fiscal policy rule identifies two regimes. There is a strong significant positive response of primary surplus to lagged public debt in regime 2 which we label sustainable, whereas the response of primary surplus to lagged 
public debt is insignificant but positive in regime 1, which we label unsustainable. They show that the United States of America (USA) government stabilizes its debt only during some periods. A relatively short-lived but tight fiscal contraction can be sufficient to ensure long-run USA debt sustainability. Finally, the main outcome of the paper is that fiscal policy in the USA has been globally sustainable since 1940.

Many economists have viewed the public deficit as harmful to the USA's and world economies, predicted by the life-cycle theory (Barro) [15]. Its effects include high real interest rate, low saving, low rate of economic growth, large current account deficit, poor performance of the economy, etc. A budget deficit leads to increased aggregate demand, obligated interest rate to increase for restoring equilibrium, but making crowding out the investment; reducing the stock of capital in the long run for future generations. Similar reasoning applies to pay-as-you-go social security programs. In an open economy, a country's budget deficit or social security programs would have negligible effects on the real interest rate on the international capital markets.

Furthermore, there are some institutional and governance variables that can also help explain the evolution of public debt in the Eurozone in our period of assessment, for instance, corruption and shadow economy. In this way, Cooray et al., (2017) [16] tested how the increasing of corruption and larger shadow economy directly affected the public debt-both are reinforced complementarity to their negative influence. However, under dynamic panel data analysis, Lee (2018) [17] has found robust evidence that increasing public debt in the Organization for Economic Co-operation and Development countries has not been attributable to social expenditure. Indeed, because public debt levels influence long-term economic growth, Liu and Lyu (2020) [18] suggested that policy makers should control its scale.

Last but not least, in the current context of the Covid-19 pandemic and its adverse effects, the European Central Bank (2020) [19] stated that the pandemic is set to weaken fiscal positions, as automatic stabilizers and discretionary measures translate into high deficits. Consequently, public debt ratios are going to follow an unsustainable path in already High Indebted Euro Countries (HIDC) if there is a more severe and prolonged economic contraction than envisaged, combined with higher sovereign funding costs and the materialization of contingent liabilities.

\subsection{Economic, Social and Institutional Data}

We have classified the variables under analysis in three subgroups: the studied dependent public debt, the explanatory and instrumental variables. Table 1 gathers the main variables involved in our study and their data sources.

Table 1. Variables and Data Sources.

\begin{tabular}{ccc}
\hline Variable Name & Definition & Source \\
\hline HIDC & $\begin{array}{c}\text { Eurozon Indebted Euro Countries } \\
\text { debt ratio of } 100 \% \text { more than once }\end{array}$ & European Central Bank \\
\hline Debt & $\begin{array}{c}\text { Ratio of public debt stock with the gross } \\
\text { domestic product in percentage }\end{array}$ & European Central Bank \\
\hline Growth & $\begin{array}{c}\text { Annual percentage growth rate of GDP at market } \\
\text { prices based on constant local currency }\end{array}$ & World Bank \\
Rate & $\begin{array}{c}\text { Long-term interest rate for convergence purposes, } \\
\text { debt security issued, 10-year maturity, } \\
\text { denominated in Euro }\end{array}$ & European Central Bank \\
\hline Balance & Current account of balance of payments, ratio to GDP & World Bank \\
\hline
\end{tabular}


Table 1. Cont.

\begin{tabular}{|c|c|c|}
\hline Variable Name & Definition & Source \\
\hline PDeficit & $\begin{array}{l}\text { Net lending/net borrowing excluding interest } \\
\text { payable (primary deficit or surplus), ratio to GDP }\end{array}$ & European Central Bank \\
\hline Unemployment & Unemployment, total (\% of total labor force) & $\begin{array}{l}\text { International Labour } \\
\text { Organization }\end{array}$ \\
\hline Life & Life expectancy at birth, total (years) & World Bank \\
\hline WGI & $\begin{array}{l}\text { Worldwide Governance Indicators: six aggregate } \\
\text { indicators, summarizing the views on the } \\
\text { governance quality }\end{array}$ & World Bank \\
\hline Democracy & Voice and accountability & World Bank \\
\hline Government & Government effectiveness & World Bank \\
\hline Control & Control of corruption index & World Bank \\
\hline Corruption & Corruption Perception Index & $\begin{array}{c}\text { Transparency International } \\
\text { Agency }\end{array}$ \\
\hline SDC (2009-2018) & Structural change caused by the sovereign debt crisis & Own study \\
\hline HICP & Harmonized index of consumer prices & European Central Bank \\
\hline PEPP & Pandemic emergency purchase program & European Central Bank \\
\hline ERTES & $\begin{array}{l}\text { Expediente de Regulación Temporal de Empleo: } \\
\text { Temporary Employment Regulation File }\end{array}$ & Spanish legislation \\
\hline Eurostat & European statistics & European Commission \\
\hline COVID-19 & Coronavirus disease & World Health Organization \\
\hline
\end{tabular}

\subsection{Public (Government) Debt}

By introducing the Euro currency in 1999, the twelve countries-Austria, Belgium, Finland, France, Germany, Greece, Ireland, Italy, Luxemburg, the Netherlands, Portugal and Spain, were making efforts to reduce their public debt ratio, as the Maastricht Treaty had fixed it up to $60 \%$, and the Public Budget Primary Balance Deficit set a roof of 3\% to the GDP. In the first five years (2000-2004) only Belgium, Greece and Italy surpassed the 100\% bound. However, by finishing the decade of the 2010s, the public debt ratio of Cyprus and Portugal had crossed this bound, whilst Ireland reached 107.5\% between 2010-2014.

For our study, we have named them as the High Indebted Euro Countries (HIDC); in particular, when the public debt ratio had reached more than $100 \%$ for at least two years in our period of assessment, because they are living on more than their own means in the short period of several years. Spain has marginally been out of this group before the Covid-19 pandemic. Meanwhile, the ratios of Austria, France, Finland, Germany, Spain, Slovenia, Malta and Netherlands were just above the $60 \%$ reference value in the last two decades, before Covid-19 pandemic. The public debt of Estonia, Luxembourg, Slovakia, Lithuania and Latvia reached less than $60 \%$ of the GDP, faithfully complying with the Maastricht Treaty.

Furthermore, in accordance with the Table 2, the coefficient of variation (Standard Deviation/Geometric Average) shows us that the behavior of this public finance indicator has been very different, in different subperiods. Indeed, it has been increasing in the context of the sovereign debt crisis. For estimated coefficient of variation, you can see the Appendix A, Table A1. 
Table 2. Average and Standard Deviation of the Public Debt-to-GDP ratio.

\begin{tabular}{|c|c|c|c|c|c|c|c|c|c|c|}
\hline \multirow{2}{*}{ Country: } & \multicolumn{5}{|c|}{ Geometric Average } & \multicolumn{5}{|c|}{ Standard Deviation } \\
\hline & 1995-1999 & 2000-2004 & 2005-2009 & 2010-2014 & 2015-2019 & 1995-1999 & 2000-2004 & 2005-2009 & 2010-2014 & 2015-2019 \\
\hline Austria & 66.091 & 66.122 & 69.728 & 82.470 & 77.895 & 2.332 & 0.648 & 5.756 & 1.036 & 6.048 \\
\hline Belgium & 123.679 & 104.315 & 93.372 & 104.185 & 102.063 & 6.630 & 5.058 & 4.746 & 2.535 & 2.892 \\
\hline Cyprus & 52.906 & 60.333 & 54.982 & 80.566 & 100.040 & 3.129 & 3.940 & 6.698 & 23.078 & 5.599 \\
\hline Estonia & 6.903 & 5.238 & 4.841 & 8.417 & 9.231 & 0.809 & 0.374 & 1.306 & 2.110 & 0.774 \\
\hline Finland & 50.504 & 41.776 & 37.046 & 52.750 & 61.396 & 5.062 & 1.165 & 3.854 & 5.406 & 1.966 \\
\hline France & 59.841 & 61.492 & 69.354 & 90.329 & 97.597 & 2.190 & 3.410 & 7.694 & 3.947 & 1.138 \\
\hline Germany & 58.218 & 60.942 & 67.244 & 79.507 & 65.486 & 2.063 & 3.002 & 3.421 & 2.567 & 5.092 \\
\hline Greece & 91.623 & 103.970 & 109.732 & 166.367 & 177.656 & 2.853 & 2.127 & 9.694 & 13.799 & 2.229 \\
\hline Ireland & 50.907 & 31.662 & 32.959 & 107.450 & 67.802 & 8.128 & 3.349 & 16.422 & 14.042 & 7.337 \\
\hline Italy & 116.507 & 106.961 & 107.903 & 126.475 & 134.764 & 2.784 & 1.867 & 4.948 & 7.308 & 0.405 \\
\hline Latvia & 11.667 & 13.534 & 14.772 & 43.150 & 38.272 & 1.977 & 1.001 & 11.681 & 3.004 & 1.706 \\
\hline Lithuania & 15.603 & 21.436 & 18.140 & 38.497 & 38.181 & 4.183 & 1.976 & 5.337 & 1.762 & 3.346 \\
\hline Luxembourg & 9.139 & 7.581 & 10.626 & 21.450 & 21.481 & 0.730 & 0.205 & 4.160 & 1.914 & 0.936 \\
\hline Malta & 45.584 & 65.981 & 65.338 & 67.386 & 50.206 & 10.873 & 4.432 & 3.356 & 2.504 & 6.321 \\
\hline Netherlands & 66.065 & 50.098 & 49.603 & 64.438 & 56.573 & 6.018 & 1.233 & 5.918 & 3.858 & 6.595 \\
\hline Portugal & 58.963 & 60.350 & 76.213 & 120.916 & 125.603 & 3.653 & 5.119 & 6.493 & 14.051 & 5.934 \\
\hline Slovakia & 32.239 & 46.211 & 32.168 & 48.556 & 50.512 & 9.135 & 4.236 & 3.188 & 6.230 & 1.749 \\
\hline Slovenia & 21.573 & 26.597 & 25.976 & 55.683 & 74.156 & 2.074 & 0.538 & 5.001 & 17.199 & 6.511 \\
\hline Spain & 62.839 & 51.048 & 41.653 & 81.148 & 98.008 & 1.917 & 4.952 & 6.703 & 17.069 & 1.577 \\
\hline
\end{tabular}

Source: European Central Bank. 
As we can see in Table 2, most of the HIDC had been also in the group of the GIIPS countries (Greece, Italy, Ireland, Portugal and Spain), which dramatically suffered from the sovereign debt crisis after the subprime mortgage crisis struck between 2007-2008. Consequently, Greece, Ireland, Italy and Portugal showed rates above $100 \%$ for several years; marginally we can also include Spain because after the sovereign debt crisis its public debt also reached $100 \%$ of the GDP once again. This leads us to the need to analyze the possibility of the existence or not of a structural break, precisely since the sovereign debt crisis (2009-2012). In Figure 1, we can see the evolution of the public debt ratio in these countries, which in most cases exhibits an increasing tendency.

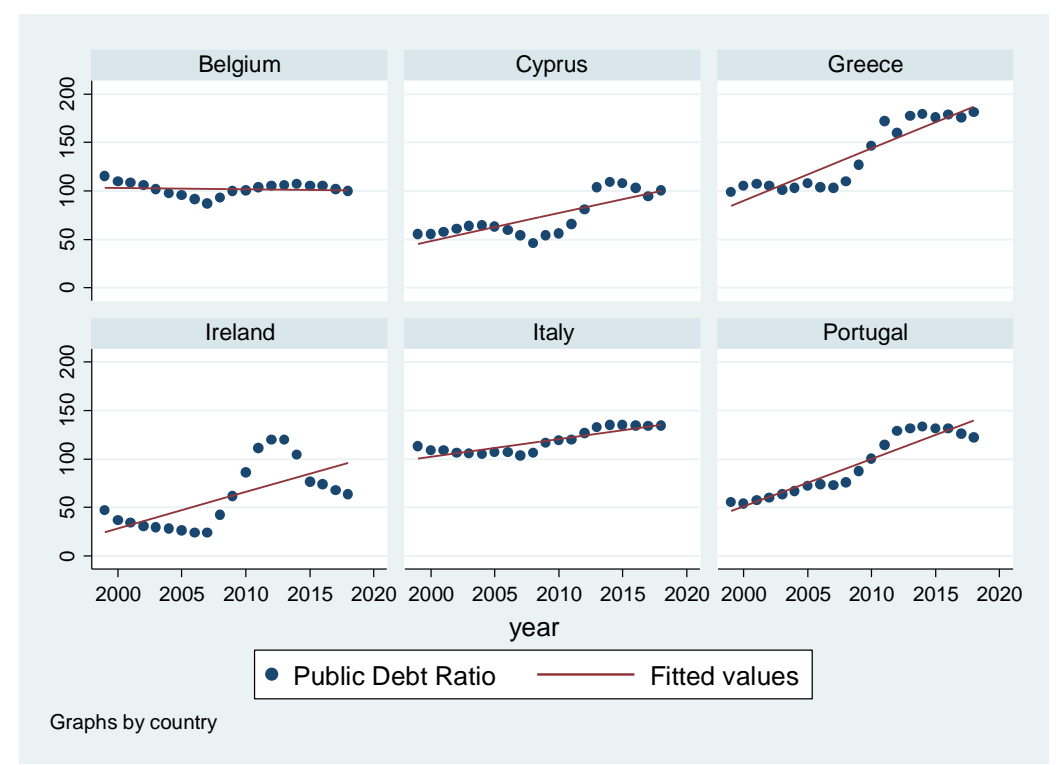

Figure 1. Public debt ratio in the High Indebted Euro Countries (HIDC). Source: European Central Bank.

Indeed, the cases of Spain and Italy are paid special attention because of the fact that they have been the most damaged Eurozone countries in the aftermath of the Covid-19 pandemic; both are increasing their public expenditures to finance the cost of the health crisis, as well as making ambitious plans of recovery for more damaged industrial sectors such as the automobile industry and tourism, among others. They have supported costly quarantines for two-three months, between March and May of 2020. Let us remember that in Spain, since the Euro inception in January, 1999, the public debt ratio was just $60 \%$, however, later, the subprime mortgage crisis of 2007 caused it to reach $35.7 \%$. After that, the indebtedness was triggered by various factors, including the bank rescuing granted in 2012 worth $€ 100,000$ million, which represents a sudden public debt increase of $10 \%$ of the GDP. By the end of 2012, the gross public debt was at $86.3 \%$ of the GDP, which clearly had been more than double of the pre-crisis level. The quadratic fit shows a growing tendency (see Figure 2).

Due to high corruption, reduction of tax collection (revenues) and increasing of social spending, the Italian public debt ratio path has been higher than other countries. Unlike the Spanish case, Italy has shown a ratio above $100 \%$ since the 1990s. After the introduction of the Euro, the government made efforts to reach the commitments of the Maastricht Treaty and the ratio decreases reached $103.9 \%$ in 2007. However, after the sovereign debt crisis (2009-2012), the public debt ratio reached $132.5 \%$, and $134.8 \%$ in the last year (2019). The accurate quadratic (exponential) fitted tendency is also clear for Italy (see Figure 1).

Unfortunately, there are different opinions about Italian public finance evolution; for some authors during the nine-year period preceding the financial crisis of 2008, Italy stood out as the worst offender of the Maastricht Treaty, sustaining budget deficits in excess of 3\% of GDP for six years straight (Henningsen) [20]. This has been the result of a vicious cycle between lack of growth and low productivity labor, social inequality and more of the poorest people with limited tax collection, 
increasing the public debt and increasing high risk score for the unpaid, which in turn increases the cost of public debt. Finally, Italy has never implemented an austerity policy to mitigate this increase.

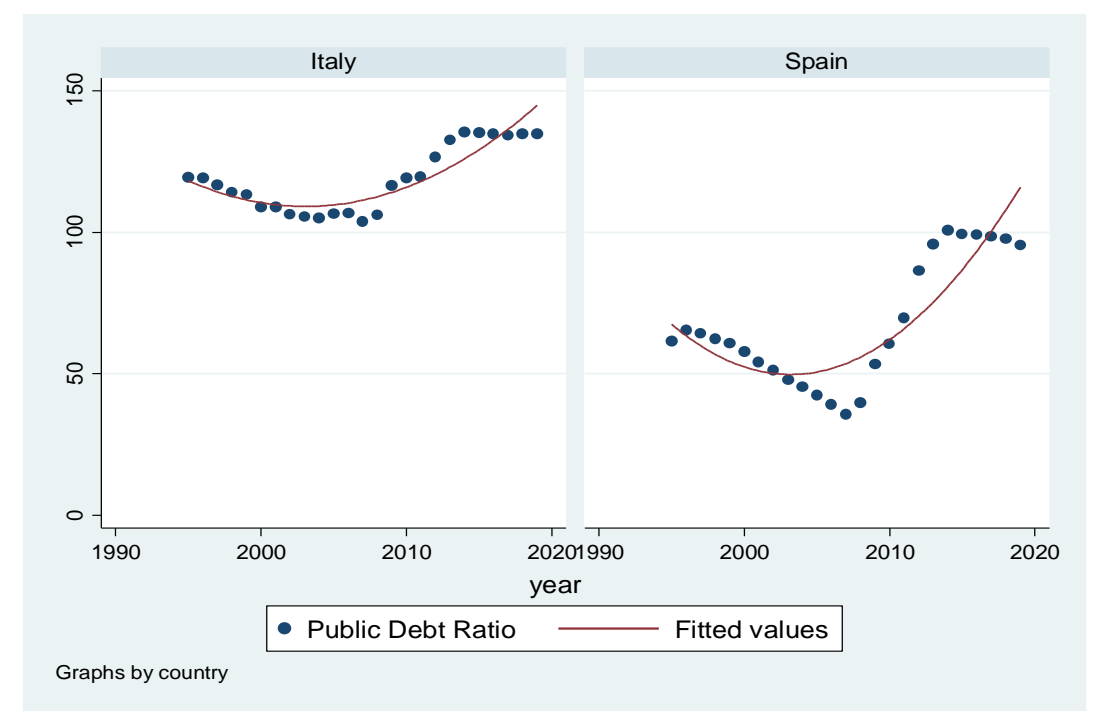

Figure 2. Spanish and Italian public debt ratio (adjusted by quadratic tendency). Source: European Central Bank.

Between 2008 and 2014, the Italian public debt ratio increased by more than 28 percent points, while the Spanish ratio increased by about 60 percent points, both regarding their current GDP. Nowadays, after the Covid-19 pandemic, with the new financing operations and generous loans of the European Central Bank and the purchase of corporation debts, it is expected that the public debt of both countries has increased much higher than the increases due to sovereign debt crisis. In accordance with International Monetary Fund projections, Italy, Portugal, France and Spain will reach public debt ratios between $150 \%$ and $115 \%$, above the average of the Eurozone (see Table 3).

Table 3. European Public Debt Amid the Covid-19 Pandemic.

\begin{tabular}{cccc}
\hline Country & $\mathbf{2 0 1 9}$ & $\mathbf{2 0 2 0}{ }^{*}$ & $\mathbf{2 0 2 1}^{*}$ \\
\hline Italy & 134.8 & 155.5 & 150.4 \\
\hline Portugal & 117.6 & 135 & 128.5 \\
\hline Francia & 98.5 & 115.4 & 116.4 \\
\hline Spain & 95.5 & 113.4 & 114.6 \\
\hline Germany & 59.8 & 68.7 & 65.6 \\
\hline Euro-zone & 84.1 & 97.4 & 95.6 \\
\hline Source: International Monetary Fund; ${ }^{*}$ ) Projections.
\end{tabular}

Indeed, there are different factors that can explain the evolution and increase of public debt in the last two decades in the Eurozone before the Covid-19 pandemic, as finance and economic variables, such as the primary balance of the public budget before interest payment, the real economic growth and the interest rates. Other kinds of socioeconomic variables are expectancy of life at birth and unemployment rate. Another group of institutional variables related to good governance are democracy, policy stability, good regulation, government effectiveness, corruption indexes, and so on. In accordance with the previous assessment of public debt, it is important to introduce a dummy variable in order to test any possible structural changes since the sovereign debt crisis (2009-2012). 


\subsection{Economic and Finance Variables}

Even though HIDC countries are reported as having the highest public debt ratio since the 1990s, only Greece, Ireland and Slovenia have shown ratios of negative primary balance of public sector (deficits) smaller than -10; regarding GDP for some years, there have even been some outliers, such as Ireland with $-30 \%$ in 2010. Meanwhile, Portugal, Cyprus and Spain have shown in some years, ratios between $-5 \%$ and $-9 \%$. In this last group we can also include Finland, Slovakia, Latvia and Lithuania that kept up with ratios less than $60 \%$ in the same time period. It seems that there is not a strict negative relationship between public debt ratio with the lag of the primary balance in the HIDC; as we can see in the Figure 3. However, public debt is the result of consecutives negative primary balance (deficits) accumulations, as well as the interest payable for the accumulated public debt.

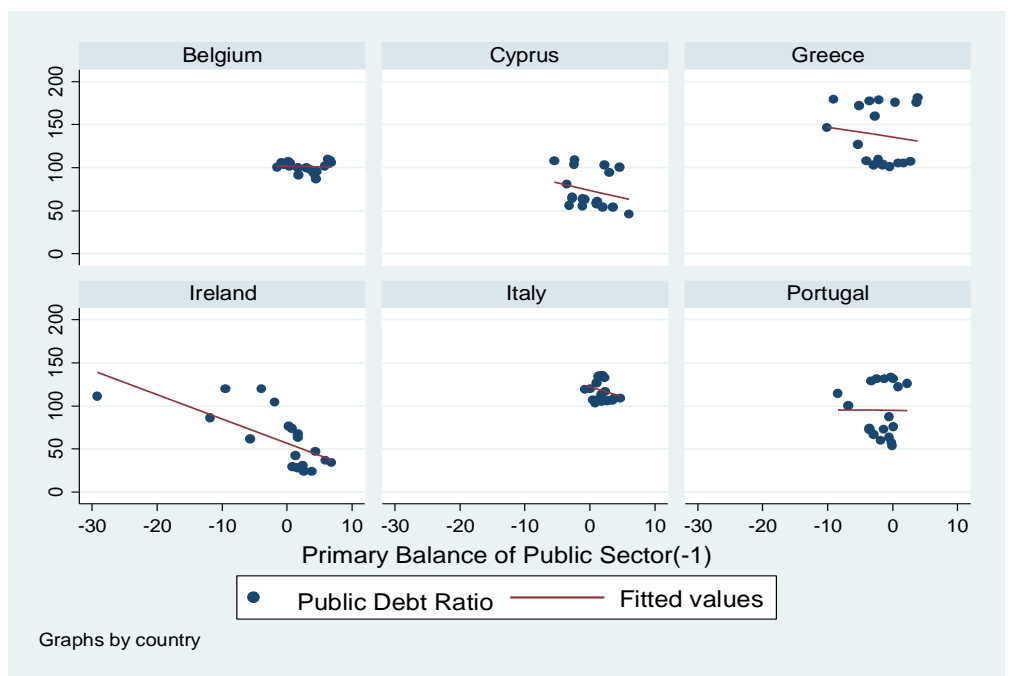

Figure 3. Primary balance of public sector (lag) and public debt ratio. Source: European Central Bank and World Bank.

There is a negative relationships between the first lag of the primary result (PDeficit(-1)) of public sector and the public debt ratio as illustrated in Figure 3. In accordance with the fitted value of the graph, there is not a homogeneous relationship in our so-called HIDC. While Greece, Ireland and Cyprus showed a negative relationship, other situations are not clear, such as Belgium and Italy, maybe because both countries had high public debt before the introduction of the Euro currency. Furthermore, Portugal also does not present any clear tendency.

Indeed, there are other factors that can explain the dynamics or evolution of the public debt ratio, as the real economic growth rate. From the annual percentage growth rate of GDP at market prices, based on constant local currency of U.S. Dollars for 2010 (World Bank Database) [21], we have subtracted the annual inflation rate to get the real rate of change of economic growth. Usually, the real growth rate of the GDP has been stationary, at around $0 \%$, however, we have some outliers such as Greece with less than $10 \%$ and Ireland with more than $20 \%$.

Usually, it is expected that an increase of the real gross domestic product reduces the public debt ratio. Figure 4 depicts these relationships for the HIDC. It seems that only for the case of Greece we can see a negative relationship. For Belgium, it is not clear. Paradoxically, for Ireland, Italy, Cyprus and Portugal the relationship is positive; consequently, the positive real economic growth increases the studied ratio. These latter findings could be revealing the presence of some unsustainability signs; however, in the next section, we present a more robust econometric analysis of these relationships. Additionally, in the context of the Covid-19 pandemic, the effect of the expected negative economic growth rate will contribute to increasing the ratio. For the first quarter of 2020, the GDP growth rate of the Eurozone has contracted by $3.6 \%$ in real terms; later, it has shrunk in the second quarter by more than $12 \%$. 


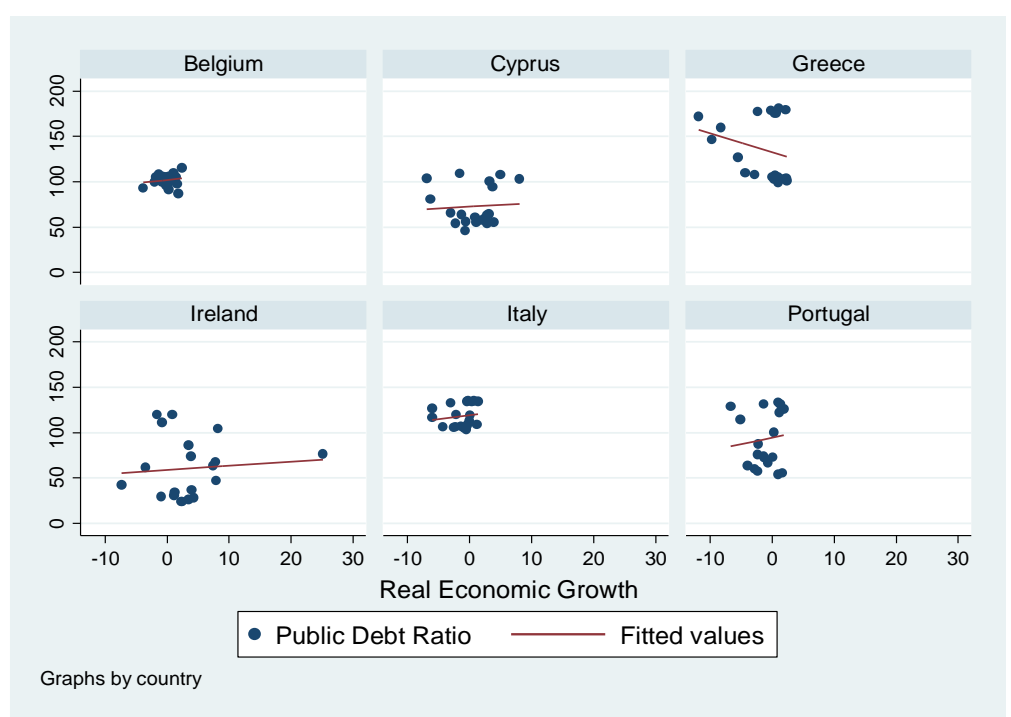

Figure 4. Real economic growth and public debt ratio. Source: European Central Bank and World Bank.

In accordance with Escolano [22], there is an important impact of the inflation rate on the public debt ratio, which should be negative because inflation can affect the real value of public debt. Consequently, we have considered implicitly as an explanatory variable the annual percentage change of the consumer price index. In accordance with Eurostat (European Commission) this is the Harmonized Index of Consumer Prices, which covers monetary expenditure on final consumption by residential and non-residential households in the economic territory of the Euro area. This inflation measure has remained relatively stable with a maximum of $10 \%$ in some countries. In accordance with our previous analysis, there is a negative impact of this variable on the public debt ratio.

Furthermore, the inflation rate can increase the nominal interest rate, which will fully offset the erosion of the public debt due to inflation, since the latter reduces its real value (Escolano) [22]. In Figure 5, we can see the evolution of the real interest rate of the HIDC, which should have a positive impact on the public debt ratio, because of the fact of increasing of the public debt service. It is noteworthy that in the figure above we have used the long-term interest rate defined as being debt security issued, with 10-year maturity, denominated in Euro. The increasing relationship between the real interest rate and the public debt ratio is clear, except for Italy and Belgium.

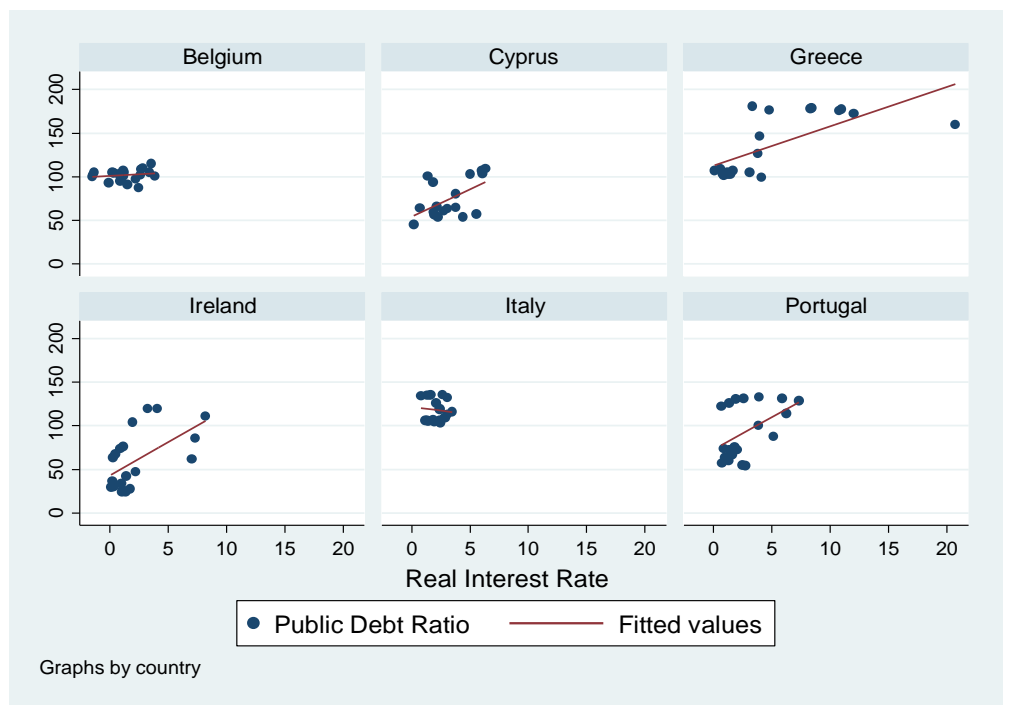

Figure 5. Real interest rate and public debt ratio. Source: European Central Bank. 
Finally, Figure 6 shows that the current account balance of payment (Balance) maintains a positive relationship with the public debt ratio-GDP, i.e., a surplus in Balance increases public debt. It should be noted that some countries present outliers that can affect the econometric results; for instance, Cyprus and Greece presented deficits around $-14.5 \%$. In accordance with international economics theory, an excessive domestic private spending in foreign goods and services may generate a deficit in the balance, which in turn can be financed with public deficit or sufficient excess of domestic saving (S) relative to national investment (I). However, as getting a domestic saving investment surplus could be cumbersome, public debt increases. The relationships for Belgium and Italy are not clear.

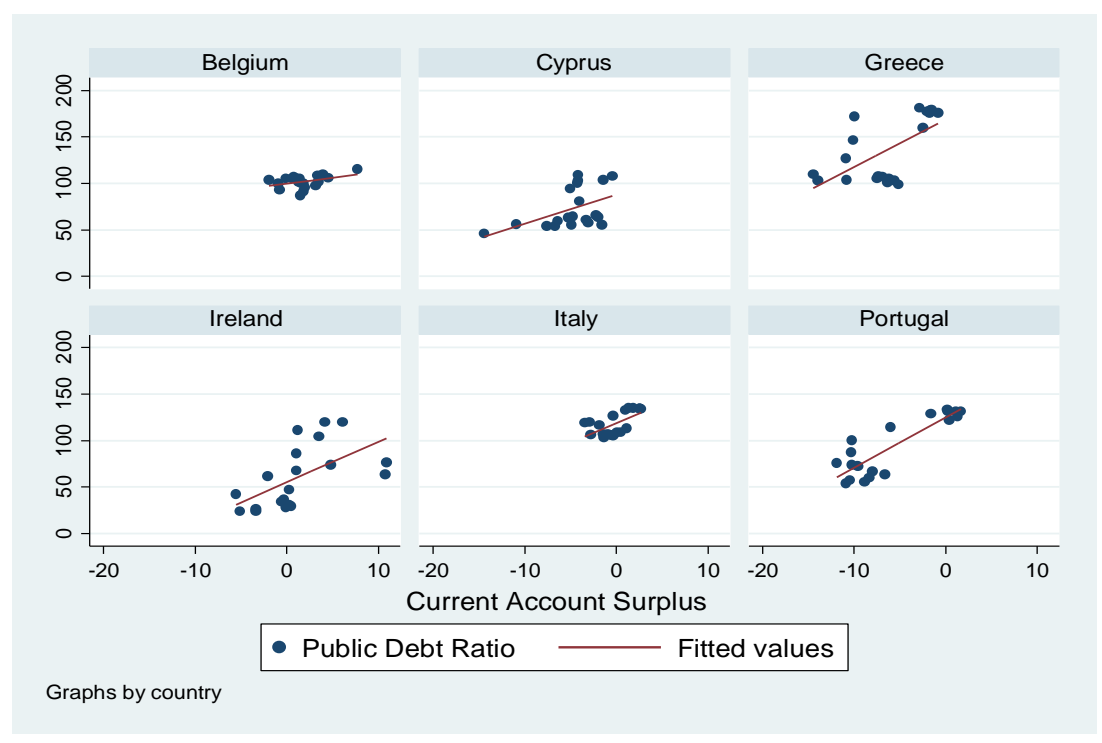

Figure 6. Current account surplus and public debt ratio. Source: World Bank.

\subsection{Socioeconomic Variables}

Different authors have pointed out that the origins of the crises in the Eurozone are demographic, not only economic and/or institutional, demonstrating that Greece, Spain, Italy and Portugal have below-replacement birth rates, with particularly low rates in the Spanish and Portuguese cases; coincidentally, these countries also have some of the highest sovereign debts in Europe, with expensive pension regimens. Under current trends, a simultaneously ageing and shrinking population will lead to a drop in tax revenue as workers retire and an increase in public expenditure as they draw pensions and resort increasingly, as the aged do, to public healthcare (Hansen and Gordon) [23]. Undoubtedly, this crisis has also been bolstered by the increase of life expectancy at birth.

In this way, another social variable that we should take into account to assess the accumulated public debt ratio is the life expectancy at birth (in total years). See Figure 7. This indicates the number of years that a newborn infant would live if prevailing patterns of mortality at the time of their birth were to stay the same throughout their life (World Bank Database) [24]. All these Euro countries have been increasing their life expectancy, reaching more than 80 years in the last decade, except Slovakia, Estonia, Latvia and Lithuania which are below 80 years; consequently, it is expected that governments spend more on public and social policies, pensions and health, in order to improve their life conditions, especially in the so-called welfare societies.

This behavior is also noted for Spain with a life expectancy at birth of more than 83 years, which coincidentally nowadays have become very damaged due to the Covid-19 pandemic, with the government being obligated to adopt different very costly measures for the public treasury. Furthermore, the North of Italy maintains a higher life expectancy of near 83. Other Euro countries with the highest index are Ireland, France, Malta and Luxembourg, with 82.6, 82.5, 82.3 and 80.1 years, respectively, in 2018. From Figure 7, it is also clear that an increase of life expectancy in Cyprus, Greece, Ireland, Italy and Portugal also increases the public debt. For Belgium, this evidence is not clear. 


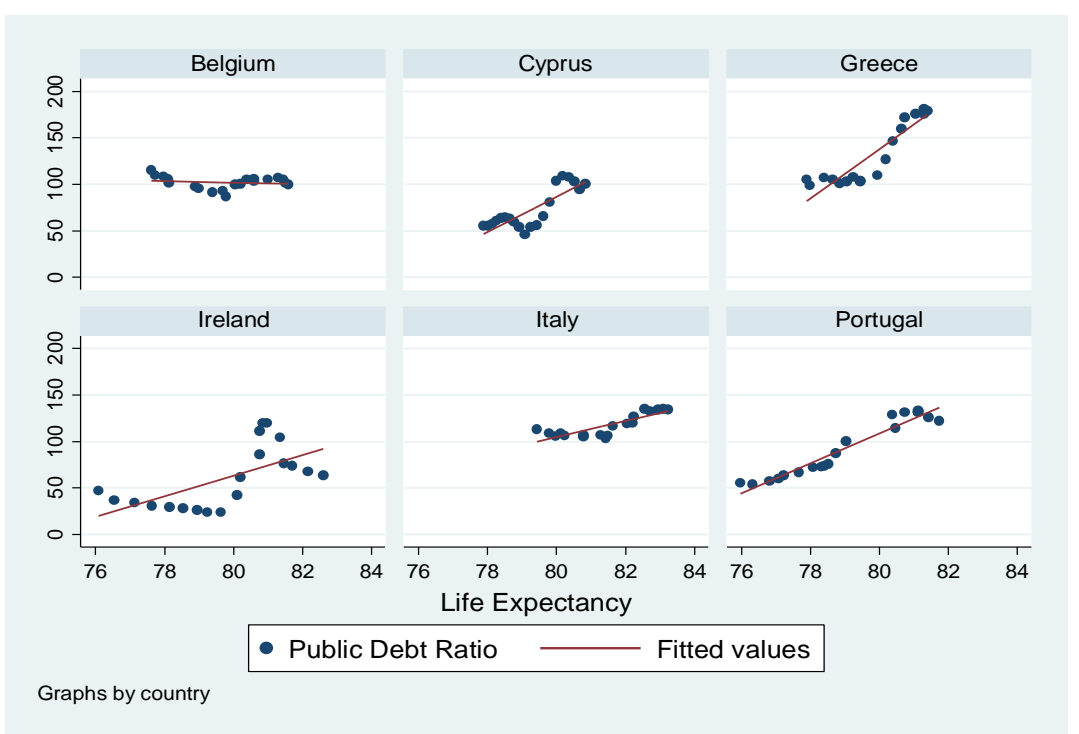

Figure 7. Life expectancy at birth and public debt ratio. Source: World Bank and United Nations.

Another important socioeconomic variable that we should take into account to assess the evolution of the public debt ratio is the unemployment rate, because unemployed workers receive unemployment benefits in Euro countries (such as ERTES in Spain), among other social benefits. The social protection benefits are transfers, in cash or in kind, made to relieve households and individuals of the burden of one or more social risks or needs (Eurostat) [25]. Our unemployment rate data is derived from the European Union Labour Force Survey and supplementary national sources (Eurostat), based on the International Labor Organization (ILO) definition. Coincidentally, HIDC have reached the highest unemployment rates; especially in the sovereign debt crisis period, with rates for Greece reaching above $20 \%$, which in turn feeds back into social public spending.

Regarding the relationship between public debt and unemployment ratios, it is supposed that an increase in this rate increases also the public debt ratio (see Figure 8), due to the cost of unemployment insurance. The fitted line between both have a positive sign, corroborating this hypothesis. This evidence is more salient in Cyprus, Greece, Ireland, Italy and Portugal governments, whilst the Belgium case is undetermined.

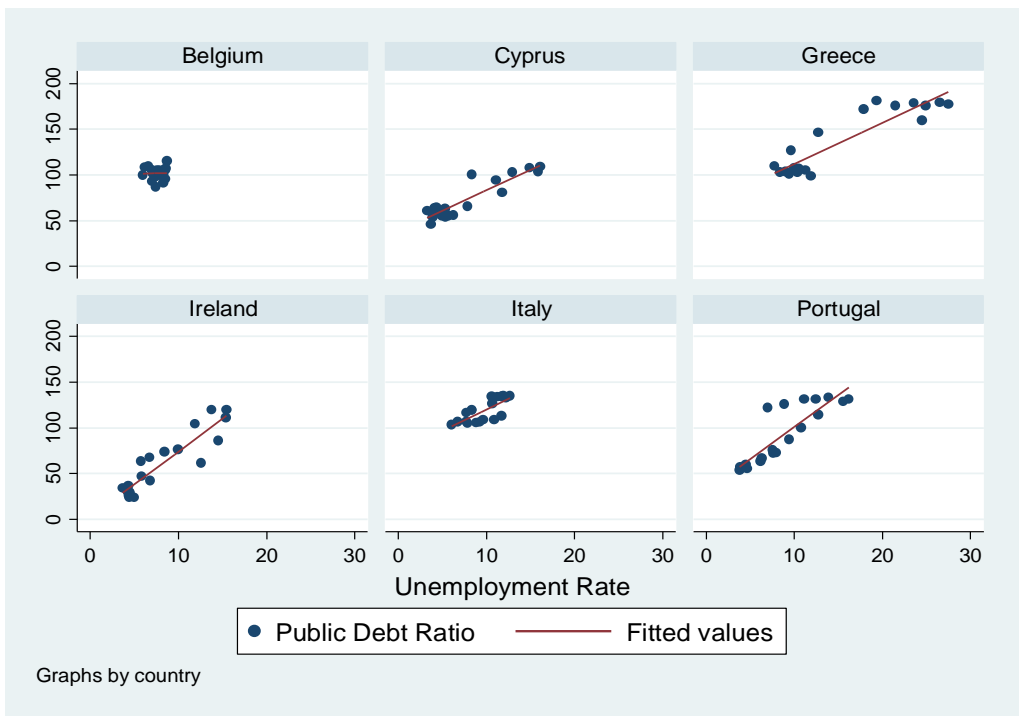

Figure 8. Unemployment Rate and the Public debt Ratio. Source: European Central Bank. 


\subsection{Governance and Institutional Indicators}

In order to comply with our aim, it is very important to assess how governance and institutional aspects can affect the action and manner of governing a state, which in turn affects their public debt evolution in the European Monetary Union; especially because there is not a Fiscal Union. These institutional aspects affect most of the countries; Southern European countries suffered from an institutional bias against structural market reforms. It is also fair to point out that for some authors the Euro crisis has been also institutional, which has been proven to be woefully inadequate in heading off or in coping with the crisis, as well as the institutions having been too weak to create consensus to implement the right Euro reforms (Hansen and Gordon) [23].

In this way, we have identified the Worldwide Governance Indicators (WGI) [26], which reflect the enforcement of institutions through which authority is exercised. These include six process indicators by which governments are selected, monitored and replaced; the capacity of the government to effectively formulate and implement sound policies; and the respect of citizens and the state for the institutions that governs economic and social interactions among them (World Bank). These six indicators are Voice and Accountability, Political Stability, Government Effectiveness, Regulatory Quality, Control of Corruption and the Rule of Law. Finally, we will also test the Corruption Perception Index from International Transparency, a non-governmental organization [27]. In what follows, we define and explore the expected relationship of these variables with the public debt ratio.

Voice and Accountability. The two are very close; this indicator is related to democratic aspects, reflects the perceptions of the extent to which a country's citizens are able to participate in selecting autonomously their governments, as well as freedom of expression, freedom of association, and a free media, which in turn allow citizens to supervise the government behavior. It denotes a specific variety of power or capacity to engage someone in reason-giving to justify their behavior and/or the capacity to impose a penalty for poor performance (Goetz and Jenkins) [28]. Democracy is also refusing publicly corruption; it seems to represent a negative relationship between public debt ratio and the Voice and Accountability indicator. However, the cost of these related activities can affect positively the public debt; indeed, these democratic activities and multiple social demands of citizens can force governments to increase their public debt.

Political Stability. In accordance with the worldwide definition, this indicator measures perceptions about the likelihood of political instability and politically motivated violence such as terrorism. Because Euro countries have not faced these kinds of problems, it is expected this indicator would not be significant. However, in other regions of the world the indicator has had a negative and significant impact, which in turn reflects on how political instability leads countries to increase the public debt ratio. On the contrary, a better perception of it reduces the public debt ratio (Tarek and Ahmed) [29]. Alternatively, we might say that there is political stability to the extent that members of society restrict themselves to the behavior patterns that fall within the limits imposed by political role expectations (Ake) [30]. We expected a negative relationship between public debt ratio and the Political Stability indicator.

Government Effectiveness. It reflects perceptions of the quality of public services and civil service and the degree of its independence from political pressures, the quality of policy formulation and implementation, and the credibility of the government's commitment to such policies (WGI). In turn, this government effectiveness indicator is determined with different factors related with characteristics of public administration, organizational and political environment, economic development and income level (Garcia-Sanchez, et al.) [31]. Better ranking in governance implies better quality of public services and public policy formulation, sound public finance and controlled fiscal deficit, which in turn could help to reduce the public debt ratio; therefore, we expect a negative relationship between both variables. However, for Middle East and North Africa (MENA) countries the coefficient of this indicator has been positive and significant (Tarek and Ahmed) [29]. It is supposed that there would be negative relationship between public debt ratio and Government Effectiveness. 
Regulatory Quality. It reflects perceptions of government abilities to formulate and implement sound policies and regulations that permit and promote private sector development, including new investment for domestic and international investors. In some studies, good regulatory quality has influenced negatively public debt (Tarek and Ahmed) [29]. The expected relationship between public debt and regulatory quality is negative. However, because of the fact that these activities can have some costs for the States, maybe this indicator can have some positive impact on the public debt ratio.

Control of Corruption. This indicator reflects perceptions of the extent to which public power is exercised for private gain, including both petty and grand forms of corruption, as well as "capture" of the state by elites and private interests (WGI). It is supposed that better control of corruption can help to reduce the public debt ratio, because good perception can result in for getting rid of any bad projects and/or unnecessary government expenses, improving the perception results in reducing the ratio. However, these activities can also have costly public policies, regulations, supervision and controls; consequently, this induces an increasing of the ratio. In accordance with our previous analysis, there is evidence for a negative impact of Control of Corruption on the public debt ratio for most of the countries, with some exceptions (Ireland and Belgium).

Rule of Law. Reflects perceptions of the extent to which agents have confidence in and abide by the rules of society, and in particular the quality of contract enforcement, property rights, the police, and the courts, as well as the likelihood of crime and violence (WGI). The rule of law is a concept that describes the supreme authority of the law over governmental action and individual behavior. It corresponds to a situation where both the government and individuals are bounded by the law and comply with it. It is the antithesis of tyrannical or arbitrary rule (Valcke) [32]. In this way, it is expected that better Rule of Law can lead to good public finance; however, it has costs for governments compliance. It is supposed that good Rule of Law has a negative impact on the public debt ratio; however, for some specific countries the relationship is positive; it is not clear in other cases.

Corruption Perception Index. Last but not least, we are considering this indicator built by Transparency International [27], which aggregates data from a number of different sources and provides perception by businesspeople and country experts of the level of corruption in the public sector. This index goes from 1 to 100.100 being the best (no perception of corruption). So, the highest Corruption Perception Index shows countries with less or maybe almost inexistent corruption. For instance, Finland and the Netherlands have been ranked better in the Eurozone. In the cases of the so-called HIDC, Spain, Ireland and Portugal have showed better indexes; on the other hand, Italy and Greece showed the worst, with indexes below 60 for the period of analysis.

It is supposed that a low corruption perception index can increase the public debt cost, because this can increase the sovereign risk score, which in turn increases the interest rate. Additionally, low index perception could show the wrong use of public funds on unprofitable social projects, or maybe bailing out some private business and banks with political support. Last but not least, a low index could be due to a poor tax revenue collection, as in Ireland, Italy and Greece in the first decade 2000s. It is expected that there would be a negative relationship between public debt ratio and the Corruption Perception Index, i.e., better corruption perception by improving transparency the less public debt ratio; however, the elasticity is different for each country.

After this qualitative ex ante assessment, we expected some relationship among these possible explanatory variables and the public debt ratio, shown in Table 4. Some of them have a positive relationship and others negative. The former is because it can help to increase the public debt ratio, such as the interest rate, life expectancy at birth, or unemployment, and the other group has a negative impact such as economic growth, government effectiveness, because an increase can help to reduce the public finance studied ratio. 
Table 4. Expected Relationship Regarding the Public debt Ratio.

\begin{tabular}{lc}
\hline Explanatory Variable & Expected Sign/Relationship \\
\hline Primary Result of Public Sector & Negative \\
Real Economic Growth & Negative \\
Consumer Price Index & Negative \\
Interest rate & Positive \\
Current Account Balance & Negative \\
Life Expectancy at Birth & Positive \\
Unemployment rate & Positive \\
Voice and Accountability & Positive \\
Political Stability & Negative \\
Government Effectiveness & Negative \\
Regulatory Quality & Negative \\
Control of Corruption & Negative \\
Rule of Law & Negative \\
Corruption Perception & Negative \\
\hline
\end{tabular}

\subsection{Instrumental Variables}

Finally, in accordance with our econometric method, we include as instrumental variables the revenues and the public spending on healthcare and the military. Public health spending estimates the current health expenditures, including healthcare goods and services consumed during each year. This indicator does not include capital health expenditures such as buildings, machinery, information technologies and stocks of vaccines for emergency or outbreaks. The military expenditures data, from the Stockholm Military International Peace Institute (SIPRI) is derived from the North Atlantic Organization (NATO). It includes current and capital expenditures on the armed and peacekeeping forces; defense ministries, defense projects agencies; paramilitary forces, if these are judged to be trained and equipped for military operations; and military space activities, including military and civil personnel, retirement pensions and social services for military personnel; operation and maintenance; procurement; military research and development. It also considers military aid.

\section{Empirical Analysis}

\subsection{Theoretic Model and Estimation Methodology}

In accordance with Escolano [22] there is a dynamic relation between primary balance $\left(p_{t}\right)$ and public debt $\left(d_{t}\right)$, because the main recursive equation governing the dynamics of the debt ratio is

$$
d_{t}=\left(1+\lambda_{t}\right) d_{t-1}-p_{t}
$$

where $\lambda_{t}=\frac{r_{t}-g_{t}}{1+g_{t}}$, with $r_{t}$ and $g_{t}$ being real interest and the GDP growth rate in period $t$, respectively.

Other authors as Aldama and Creel [14] used the following fiscal rule

$$
p_{t}=a+\gamma d_{t-1}+a_{x} x_{t}+a_{g} s_{t}+u_{t}
$$

to assess the sustainability of the US Public debt, where $p_{t}$ is the primary surplus-ratio-GDP, $d_{t-1}$ is the public debt ratio by the end-of-last period, $x_{t}$ is the output gap and $s_{t}$ is the cyclical real public spending. This simple linear fiscal policy rule generally displays auto-correlation; therefore, it estimates a model with first-order autoregressive residuals: $u_{t}=(1-\rho L)^{-1} \varepsilon_{t}$, with $\varepsilon_{t}$ representing white noise.

Furthermore, Chalk and Hemming [33], following the same theoretic structure, established this static budget constraint to study the sustainability of the public debt:

$$
d_{t+1}=\left(1+r_{t}\right) d_{t}+p_{t}
$$


where $d_{t}$ is the Government Debt Securities (Bonds) in the beginning $t, p_{t}$ the Primary Balance (Fiscal Deficit, excluding the interest payment) and $\left(1+r_{t}\right)$ the discounted factor between the present $(t)$ and the future $(t+1)$.

Sustainability implies that sum of future primary surplus $\left(p_{t}<0\right)$ values exceeds the present value of future primary deficit $\left(p_{t}\right)$. This must be in a sufficient value that covers the difference between initial debt stock $\left(d_{t}\right)$ plus the present value of the terminal $(T \rightarrow \infty)$ debt stock $\left(d_{t+T+1}\right)$, in the infinity period. It must also hold the following intertemporal budget constraint:

$$
d_{t}=-\sum_{j=0}^{\infty} R(t, t+j)^{-1} d_{t+j}+\lim _{T \rightarrow \infty} R(t, t+T)^{-1} d_{t+T+1}
$$

where $R$ represents the factor of discounts between $t$ and $t+j$; as well as $t$ and $t+T$.

Because sustainability implies no Ponzi game (governments must not have accumulated any debts by the end), it must be maintained that

$$
\lim _{T \rightarrow \infty} R(t, t+T)^{-1} d_{t+T+1} \leq 0 .
$$

Consequently, a sustainable fiscal policy should comply the follow dynamic structure for the public debt:

$$
d_{t}=-\sum_{j=0}^{\infty} R(t, t+j)^{-1} d_{t+j}
$$

For this purpose, we studied the evolution of the logarithm of public debt ratio (LDebt) in terms of a (stationary) first order autoregressive process that depends on the primary balance of public sector (PDeficit) and other variables: the economic real growth rate (Growth), the log run interest rates (Rate) and the current account surplus (Balance) as main economic determinants. In addition, we include other socioeconomic and institutional factors, such as the life expectancy at birth (Life), the unemployment rate (Unemployment), and four governance indicators: Voice and Accountability (Democracy), Government Effectiveness (Government), Corruption Perception Index (Corruption) and Control of Corruption (Control). All in all, the dynamic relation can be expressed as follows:

$$
\begin{aligned}
\text { LDebt }_{i t}=\beta_{0}+ & \beta_{1} \text { LDebt }_{i t_{i t-1}}+\beta_{2} \text { Growth }_{i t}+\beta_{3} \text { Rate }_{i t}+\beta_{4} \text { Balance }_{i t}+\beta_{5} \text { PD ficict }_{i t-1} \\
& +\beta_{6} \text { Life }_{i t}+\beta_{7} \text { Unemployment }_{i t}+\beta_{8} \text { Democracy }_{i t}+\beta_{9} \text { Government }_{i t} \\
& +\beta_{10} \text { Corruption }_{i t}+\beta_{11} \text { Control }_{i t}+\alpha_{i}+\varepsilon_{i t}
\end{aligned}
$$

where $\alpha_{i}$ captures the idiosyncratic effects for every High Indebted Euro Country.

The main objective of this paper is to provide a panel data model that allows to explain the main determinants of the public debt in the Eurozone, since their conformation, including the last sovereign debt crisis. Panel data models were derived for optimally exploiting the cross-section and time-series structure of the data, as well as controlling for unobserved heterogeneity. These issues are intrinsic in our study, where not all governments take actions in the same way, even though they share the same observable characteristics; therefore, we should contemplate unobservable latent effects, specific characteristics for each country and general constants at the time of assessment. Under possible correlations between latent effects and explanatory variables, the ordinary least squares (OLS) method reports inconsistent estimators. Moreover, both fixed and random effects regressions produce biased estimations when the model presents dynamic relations. These are the endogeneity problems inherent to panel data, namely, unobserved heterogeneity, simultaneity or dynamic endogeneity (see Ullah et al., 2018 [34], for a comprehensive description on the methods to deal with all these endogeneity sources). Particularly, the generalized method of moments (GMM) allows dealing with all these problems by removing endogeneity with first-differencing of the model and using lagged values of the variables as valid instruments. This procedure also presents some limitations since it produces first-order autocorrelation that should be taken into account and presents potential losses of observations 
in incomplete panels. This latter problem is solved with two-step GMM (i.e., forward orthogonal deviations), which is implemented in system GMM estimation.

In this way, the models in Equation (7) are estimated with a panel-composed data from the Eurozone nineteen (19) countries, spanning over the period between 1999 and 2018. This data panel satisfies the assumptions derived by Roodman (2009) [35] to implement GMM estimation: regressors that are endogenously determined, dynamic relationships, idiosyncratic disturbances uncorrelated across countries, potential regressors not strictly exogenous, panels with a long cross section. In order to achieve consistent estimations, we applied four variants of the general method of moments (GMM): Two types of System GMM and two stages least squares (2SLS) with clusters. System GMM eliminates the potential sources of omitted variables bias in estimation, controlling for the endogeneity problem by considering the lagged level variables as instruments of the variables in the difference equation (Arellano and Bover, 1990 [36]); (Blundell and Bond, 1998 [37]). Cluster analysis attempts to determine the natural groupings (or clusters) of observations by countries and fits linear models where one or more of the regressors are endogenously determined with GMM to correct the heterogeneity problems of residuals. Furthermore, the 2SLS estimation accounts for potential endogeneity problems from Primary Balance of Public Sector (PDeficit), using total current revenues, health and military expenditures as instrumental variables.

\subsection{Econometric Results}

Table 5 displays the best model specifications after testing many other alternatives with different explanatory variables. The models consider all nineteen (19) Euro countries, and different explanatory variables as control of corruption, which resulted significantly in the first and third regressions. On the contrary, when we included corruption perception as explanatory variables in the second and fourth regressions, it did not result as significant to explaining the behavior of the dependent variable $L D e b_{t}$. All of them are also controlled by the particular impact of the sovereign debt crisis with a dummy $\left(S D C_{p}\right)$, that scores 1 in the period 2009-2018 and zero in the rest of the sample.

The System GMM estimations present the typical autocorrelation pattern in the first difference estimation autocorrelation AR (1) and absence of second order autocorrelation AR (2). Furthermore, Sargan and Hansen tests support the validity of the instruments of the procedure. It is also worth noting that $p$-values in Table 5 correspond to 'robust' estimations for standard errors, i.e., consistent with heteroskedasticity and autocorrelation corrections. The results from System GMM 1 and Instrumentalized GMM-Cluster 1 regressions seem to be robust with the estimation method. In particular, the coefficients are significant, they maintained their sign, and some of them are very similar, including the Control of Corruption (Control), which reflects the consistency of our estimations.

Table 5. Estimations for the Logarithm of Public debt Ratio (LDeb).

\begin{tabular}{ccccc}
\hline $\begin{array}{c}\text { Explanatory } \\
\text { Factors }\end{array}$ & $\begin{array}{c}\text { System } \\
\text { GMM 1 }\end{array}$ & $\begin{array}{c}\text { System } \\
\text { GMM 2 }\end{array}$ & $\begin{array}{c}\text { Instrument. } \\
\text { GMM-Cluster 1 }\end{array}$ & $\begin{array}{c}\text { Instrument. } \\
\text { GMM-Cluster 2 }\end{array}$ \\
\hline $\begin{array}{c}\text { Intercept } \\
(p \text {-value })\end{array}$ & -0.7825 & $(0.6527$ & -0.6632 & $(0.6791$ \\
\hline LDebt $(-1)$ & $(0.073)$ & $(0.102)$ & $(0.024)$ & $(0.032)$ \\
$(p$-value $)$ & $(0.9098$ & 0.9265 & 0.9175 & 0.9301 \\
\hline Growth & -0.0078 & $(0.000)$ & $(0.000)$ & $(0.000)$ \\
$(p$-value $)$ & $(0.000)$ & $(0.000)$ & -0.0072 & $(0.000)$ \\
\hline Lrate & 0.0196 & 0.0210 & 0.0243 & $(0.000)$ \\
$(p$-value $)$ & $(0.014)$ & $(0.021)$ & $(0.003)$ & 0.0225 \\
\hline Balance & 0.0013 & 0.0011 & 0.0012 & $0.006)$ \\
$(p$-value $)$ & $(0.070)$ & $(0.132)$ & $(0.083)$ & 0.0011 \\
\hline
\end{tabular}


Table 5. Cont.

\begin{tabular}{|c|c|c|c|c|}
\hline $\begin{array}{l}\text { Explanatory } \\
\text { Factors }\end{array}$ & $\begin{array}{l}\text { System } \\
\text { GMM } 1\end{array}$ & $\begin{array}{l}\text { System } \\
\text { GMM } 2\end{array}$ & $\begin{array}{c}\text { Instrument. } \\
\text { GMM-Cluster } 1\end{array}$ & $\begin{array}{c}\text { Instrument. } \\
\text { GMM-Cluster } 2\end{array}$ \\
\hline $\begin{array}{l}\text { PDeficit }(-1) \\
\quad(p \text {-value })\end{array}$ & $\begin{array}{c}-0.0028 \\
(0.000)\end{array}$ & $\begin{array}{c}-0.0030 \\
(0.000)\end{array}$ & $\begin{array}{c}-0.0030 \\
(0.016)\end{array}$ & $\begin{array}{c}-0.0050 \\
(0.003)\end{array}$ \\
\hline $\begin{array}{l}\text { LUnemployment } \\
\qquad(p \text {-value })\end{array}$ & $\begin{array}{l}0.0369 \\
(0.032)\end{array}$ & $\begin{array}{l}0.0309 \\
(0.045)\end{array}$ & $\begin{array}{l}0.0302 \\
(0.013)\end{array}$ & $\begin{array}{l}0.0142 \\
(0.418)\end{array}$ \\
\hline $\begin{array}{c}\text { Llife } \\
\text { (p-value) }\end{array}$ & $\begin{array}{l}0.4827 \\
(0.045)\end{array}$ & $\begin{array}{l}0.3952 \\
(0.071)\end{array}$ & $\begin{array}{l}0.4125 \\
(0.014)\end{array}$ & $\begin{array}{l}0.4161 \\
(0.021)\end{array}$ \\
\hline $\begin{array}{l}\text { dLDemocracy } \\
(p \text {-value })\end{array}$ & $\begin{array}{l}0.3384 \\
(0.017)\end{array}$ & $\begin{array}{l}0.3066 \\
(0.033)\end{array}$ & $\begin{array}{l}0.3939 \\
(0.024)\end{array}$ & $\begin{array}{l}0.4051 \\
(0.040)\end{array}$ \\
\hline $\begin{array}{l}\text { Government } \\
(p \text {-value })\end{array}$ & $\begin{array}{c}-0.0012 \\
(0.009)\end{array}$ & $\begin{array}{l}(0.0003 \\
(0.308)\end{array}$ & $\begin{array}{c}-0.0010 \\
(0.002)\end{array}$ & $\begin{array}{l}(0.0004 \\
(0.164)\end{array}$ \\
\hline $\begin{array}{l}\text { Control } \\
(p \text {-value })\end{array}$ & $\begin{array}{l}0.0009 \\
(0.014)\end{array}$ & -.- & $\begin{array}{l}0.0008 \\
(0.000)\end{array}$ &.-- \\
\hline $\begin{array}{l}\text { Corruption } \\
\text { ( } p \text {-value })\end{array}$ & -.- & $\begin{array}{l}0.0002 \\
(0.344)\end{array}$ & -.- & $\begin{array}{l}0.0002 \\
(0.169)\end{array}$ \\
\hline $\begin{array}{c}\text { SDC } \\
(2009-2018) \\
(p \text {-value })\end{array}$ & $\begin{array}{l}0.0268 \\
(0.002)\end{array}$ & $\begin{array}{l}0.0243 \\
(0.002)\end{array}$ & $\begin{array}{l}0.0268 \\
(0.000)\end{array}$ & $\begin{array}{l}0.0221 \\
(0.001)\end{array}$ \\
\hline $\begin{array}{l}\text { Arell.-Bond } \\
\qquad \operatorname{AR}(1) \\
(p \text {-value })\end{array}$ & $\begin{array}{l}-2.49 \\
(0.013)\end{array}$ & $\begin{array}{l}-2.40 \\
(0.016)\end{array}$ & -.- &.-- \\
\hline $\begin{array}{l}\text { Arell.-Bond } \\
\text { AR }(2) \\
(p \text {-value })\end{array}$ & $\begin{array}{c}1.19 \\
0.233\end{array}$ & $\begin{array}{c}1.27 \\
(0.205)\end{array}$ &.-- & -.- \\
\hline $\begin{array}{l}\text { Sargan } \\
\text { (p-value) }\end{array}$ & $\begin{array}{l}276.80 \\
(0.189)\end{array}$ & $\begin{array}{l}277.35 \\
(0.161)\end{array}$ & -.- & -.- \\
\hline $\begin{array}{l}\text { Hansen } \\
(p \text {-value })\end{array}$ & $\begin{array}{c}1.53 \\
(1.000)\end{array}$ & $\begin{array}{c}1.22 \\
(1.000)\end{array}$ & -.- & -.- \\
\hline
\end{tabular}

The table includes panel data regressions estimated by System GMM (columns 1 and 2) and Instrumentalized Cluster (columns 3 and 4). LDebt(-1): First lag of the logarithm of public debt-GDP ratio; Growth: real economic growth rate; LRate: logarithm of nominal interest rate of bond with maturity at 10 years; Balance: current account of balance of payments-GDP ratio; PDeficit(-1): First lag of primary result of public sector budget-GDP ratio; LUnemployment: logarithm of the unemployment rate; LLife: logarithm of the life expectancy at birth; dLDemocracy: logarithm-difference of the Voice and Accountability indicator; Government: Government Effectiveness indicator; Control: Control of Corruption indicator; Corruption: Corruption Perception Index; SDC: Dummy variable for all Euro countries scoring 1 during and after the sovereign debt crisis (2009-2018) and 0 otherwise. $p$-values for statistics robust to heteroscedasticity in parentheses.

\subsection{Economic and Finance Explanatory Variables}

As we expected, the lag of the dependent variable, LDebt(-1), has a positive and significant effect on the dependent variable LDebt, which has proven the dynamic nature of public debt accumulation. The lagged public debt also influences on the current level. In this process the Primary Balance of Public Sector (PDeficit), has a determinant role in the public debt. Particularly, we found significant evidence of a strictly negative feedback effect of the lagged primary fiscal balance (PDeficit $(-1)$ ) on the public debt. Therefore, a negative lag of primary balance results increases the logarithm of the accumulated public debt ratio, and vice versa, a positive result (surplus) decreases the ratio; in both cases as a percentage of the GDP. This is because the public debt is linked to the results of the public sector; similarly, the external debt is linked to the evolution of the primary current account balance (Wyplosz) [10].

It is also fair to point out that we use as an explanatory variable the lag of the primary result of public sector (PDeficit $(-1))$ in order to avoid the endogeneity problem between contemporaneous values 
of this variable and the public debt (LDebt), because of limitations of outside instruments; furthermore, this natural instrument contains information on the current value of the variable as there is, frequently, a delay between the decision made by individuals and its actual realization (Pindado et al., 2014) [38]. Even though there is not a homogeneous relationship between the PDeficit $t_{t}$ and the public debt ratio for each country (for some it is positive, for others negative, or it is not clear, see Figure 3), in accordance with our econometric estimations, on average the relationship is negative, as we expected (see Table 3). Consequently, a positive point percent increasing in the PDeficit $(-1)$ leads to a reduction of the public debt ratio by about $0.28-0.30 \%$, keeping the other explanatory variables. The PDeficit represents the policy fiscal of each country, the difference between tax collection and public current spending. It does not include the interest payable.

While the real economic growth rate has a significant and negative impact, a positive economic growth rate reduces the public debt ratio. Furthermore, the GDP is the denominator of this ratio. Therefore, a percent point economic growth increases, allowing to reduce about $0.78-0.72 \%$ the public debt ratio. On the other hand, the logarithm of the (nominal) interest rate has a positive and significant impact, so an increase of the cost by one percent point increases also the studied ratio by about $0.020-0.024 \%$, keeping the other explanatory variables. In this way, policy makers should have to respond to the changing conditions in their tax base (economic growth) and the cost of finance or interest rate (Collignon) [11]; especially nowadays, as it is very low after huge quantitative easing adopted by the European Central Bank to buy public debt (and corporation debt) during the Covid-19 pandemic.

However, the nominal interest rate (Lrate) is sensitive; when we introduce the Sovereign Risk Score as an explicit explanatory variable, the significance of the nominal interest rate is notably reduced. This could be because the interest rate implicitly incorporated the Sovereign Risk Score; when it increases, so does the interest rate. Therefore, by keeping it out we have eliminated collinearity. It is also fair to point out that we have controlled by the real interest rate, without inflation, which is also positive but not significant according to the results, to explain the evolution of the public debt ratio.

Regarding the international finance variables, the coefficient of the Current Account Balance of Payment as a percentage of the GDP (Balance), the impact on the studied ratio is positive and significant. This indicator provides us with information about goods, services and other primary transactions, excluding the financial transactions of each Euro country resident regarding the rest of the world. Therefore, in accordance with this econometric result, a point increases in the Balance also increases the public debt ratio by $0.12-0.13$ percent, keeping the other explanatory variables; consequently, a surplus of the Balance would lead Euro countries to increase their public debt ratio. It could be interpreted/inferred that a current account surplus (Balance $>0$ ), i.e., the accumulation of Eurozone resident investments abroad, is also indirectly financed with public debt.

\subsection{Socioeconomic Variables}

Unemployment rate and Life expectancy at birth. The logarithm of unemployment rate (LUnemployment) and the logarithm of the life expectancy at birth (Llife) have positive and significant effects on this public debt ratio, keeping the other explanatory variables constant. Undoubtedly, unemployment insurance is another cost that Euro governments are faced with and has also been used as a macroeconomic political instrument to boost the economy. One-point increases of unemployment, also increases the studied ratio by 0.037 , retaining the other explanatory variables. Naturally, both imply public spending that affects negatively the stock of capital and the real economy growth in the long run, in accordance with Barro [15].

Different discussions around unemployment insurance schemes have said in some countries they are more generous and/or more effective than others, and recommended that they should be built in a homogeneous way in the European Economic and Monetary Union. Furthermore, the divergence in unemployment rates experienced in the aftermath of the Great Depression (1929) reinforces the idea of a common stabilization mechanism. In this way, implicit unemployment insurance has also been considered as an ideal solution for an anti-cyclical expenditure mechanism (Beblavý) [39]. 
As far as the coefficient of Expectancy Life at Birth is concerned, the effect is positive and significant, which means that an increase of life expectancy in one year also increases the studied fiscal ratio by about 0.48 (half point, approximated). There are different possible explanations: this leads governments to increase their public pensions and prevention systems funds in order to finance the future long life of European citizens, as well as the public health system prevention to take care old people (as residences for the elderly). For instance, Spain and Italy are inhabited by people with the highest longevity in the world, after Japan; recently, Spain passed the law of Minimum Vital Income.

\subsection{Institutional Quality Indicators}

The six World Governance Indicators tested in our econometric models have different impacts on the public debt ratio. Only three of them appeared to be significant: Voice and Accountability (Democracy), Government Effectiveness (Government) and Control of Corruption (Control). The first two resulted as the expected effect (relationship). The first logarithm-difference of Voice and Accountability (dLDemocracy) is significant and positive, showing that an exchange rate increase of the Voice and Accountability indicator has a positive impact on the studied ratio, because of the fact that these democratic related activities allowed citizens to get public finance support for necessary social and productive projects to be developed by the government, which in turn puts pressure on the public debt ratio. Additionally, this result can be interpreted as an improvement of institutions in assuming responsibilities and accepting consequences for their decisions, forcing Euro states to increase their public debt because of their cost.

On the other hand, the relationship between the Government Effectiveness (Government) indicator and public debt ratio is negative and significant. This means that better public services perception, good public planning and public policy formulation quality improvements lead to better public finance, which in turns contributes to reducing the public debt ratio, as we expected. A one-point increase of the Government Effectiveness indicator (Government) causes a reduction of about 0.12 point of the studied public debt ratio in the Eurozone, when keeping the other explanatory variables.

The Control of Corruption (Control) from the WGI requires special attention. Its coefficient is positive and significant (first column), as well as in our instrumentalized GMM cluster model (third column). Consequently, an increase in this indicator, due to improvements in control of corruption mechanisms, also increases the public debt ratio, which seems to be paradoxical. These findings show that improvements of control of corruption have influenced positively the ratio. On the other hand, when we tested the Corruption Perception Index (Corruption) built by the Transparency International non-governmental organization, its coefficient was not significant to explaining the evolution of the public debt ratio logarithm in the GMM-2 model (second column) and also in the case of GMM Cluster-2 model (fourth column).

Undoubtedly, it seems irrelevant to consider both variables Control and Corruption at the same time because they are highly correlated. Indeed, the second index included implicitly the Government Effectiveness. This possible nonlinear relationships were also assessed in our econometric estimations by including multiplicative effects between some institutional indicators, such as Government Effectiveness $\times$ Control of Corruption, as well as the Government Effectiveness $\times$ Corruption Perception; however, both new variables failed to produce any significant coefficient, both in level and in logarithm.

These results can be caused by this indicator, which could measure also the ratio of "public debt financing capacity"; that is, the less corrupt a country is perceived to be because of improving controls against it, the more it can finance itself through debt (maybe the cost of financing is lowering). For this reason, countries that are perceived as not being very corrupt can resort to this resource more by increasing their public debt ratio. Furthermore, this could mean that public activities to improve the perception about corruption have important costs to such an extent that it increases the public debt ratio. On the other hand, when the index is reduced, as the perception of corruption worsens, the ratio reduces in parallel. 
The results are also similar to research findings for other regions. For instance, for the Middle East and North of Africa (MENA), the impact of this WGI have also been positive and significant. The estimated long-run effects of Tarek and Ahmed [29] suggested that one-unit point increases in the Control of Corruption indicator leads to an increase of approximately $0.006 \%$ in the public debt ratio. For these authors, this can support "the romantic view of corruption", whereby a smaller corruption control indicator could improve businesses and boost economy growth when institutions and bureaucracy are ineffective; consequently, public debt ratio would also decrease. On the contrary, higher control of corruption can reduce GDP and increase public debt ratio.

In other studies, such as Kim et al. [40], the interaction between public debt and corruption is a statistically significant variable to explain economic growth, which reinforced the hypothesis that the marginal effects of public debt on economic growth are a function of corruption. Even if the threshold differentiating the sign of the marginal effect is dependent upon the models selected, the authors concluded that in the case of a highly transparent (low corruption) country, public debt enhances economic growth and vice versa. The authors concluded that the institutional quality of better corruption perception can play a very important role in determining the effects of public debt policies. Finally, in our Euro panel data analysis, the other three World Governance Indicators (Political Stability, Regulatory Quality and the Rule of Law) were not significant to explain the evolution of the public debt ratio since the inception of the Euro.

\subsection{Sovereign Debt Crisis (2009-2012)}

Last but not least, for our aim it is very important to test the effect of the sovereign debt crisis (2009-2012) on the evolution of the public debt ratio. Therefore, when we tested the dummy of transitory changes $\left(\mathrm{SDC}_{\mathrm{t}}\right)$ caused by it; this has been proven to be statistically not significant. However, when we tested the dummy of structural changes $\left(\mathrm{SDC}_{\mathrm{p}}\right)$, permanent changes, where $\mathrm{SDC}=1$ for observations 2009-2018, otherwise 0 (for observation 1999-2008), this has been significant and positive. This approach is equivalent to a Chow test for the model intercept. The dummy variable approach has distinct advantages, as it not only tells if the two subperiods are different but also may pinpoint the source(s) of the difference-whether it is due to the intercept or the slope or both (Gujarati) [41].

\subsection{Elasticities and Possible Collinearity}

To sum up, in accordance with our econometric results, because of the fact that in average the real economic growth (Growth $>0$ ) and the lagged positive fiscal balance (PDeficit $(-1)>0$ ) led to reducing the logarithm of the public debt ratio in Euro countries, the sum of their impacts should be greater than the aggregated impacts of the nominal interest rate (LRate), logarithm life expectancy at birth (LLife) and the logarithm of unemployment rate (LUnemployment), ceteris paribus, in order to get a sustainable public debt ratio in the long run. Furthermore, it is important to recall that the final effect also depends on specific country effects, since the social reality, labor markets, structural economy and productivity for each Euro country can be very different from others. However, this unobserved heterogeneity has been controlled by the panel data approach. In the Table 6, we have summarized the public debt-GDP ratio elasticities regarding the different explanatory factors.

Table 6. Short-Run and Long-Run Elasticities Regarding the Public debt.

\begin{tabular}{ccccccccccc}
\hline Time & Growth & Rate & Balance & PDeficit (-1) & Unemployment & Life & Democracy & Government & Control & SDC \\
\hline $\mathrm{Sr}$ & -0.78 & 0.02 & 0.13 & -0.28 & 0.04 & 0.48 & 0.0034 & -0.12 & 0.09 & 2.68 \\
\hline $\mathrm{Lr}$ & -8.65 & 0.22 & 1.44 & -3.10 & 0.44 & 5.35 & 0.0377 & -1.33 & 0.998 & 29.71 \\
\hline
\end{tabular}

Sr: Short run; Lr: Long run.

Finally, we assessed any possible multicollinearity between the explanatory variables, especially among the institutional indicators, by estimating the correlations matrix of them. It seems that only there is possible collinearity between "Government Effectiveness" and "Control of Corruption", as well as 
among "Government Effectiveness" and "Corruption Perception". It could be because the better effectiveness of the government leads also to reducing corruption by controlling it, increasing the indicator of control of corruption value (or maybe the corruption perception index). Vice versa, a higher control of the corruption indicator leads to improving the perception of the quality of public and civil services and the quality of policy formulation and implementation. However, in order to illustrate better the explanatory factors' behavior, we have decided to maintain both on the right-hand side of our estimated models.

\section{Discussion}

The Covid-19 pandemic health crisis is definitely changing the way of making public finance and other public policies in the Eurozone, not only to track their finance and institutional factors, but also the social security and healthcare systems. It is well known how the expectancy of life at birth has been increasing in the Eurozone countries in the last decade, which in turn affects social expenditure, such as healthcare, retirement pensions and nursing homes. Indeed, the public health spending on innovation, research and development (R\&D) to prevent any future illness and pandemics will determine also the path of public finance. Additionally, it is a necessary condition to improve salary and labor conditions for healthcare staff at different levels. Therefore, it is important to assess the current determinants of the public debt to have more elements of judgment for a major sustainability assessment of public debt amid the Covid-19 pandemic.

In accordance with our econometric assessment, a point increase in the real economic growth rate reduces by more than half point the public debt ratio. In this way, the Eurozone economic growth is projected to evolve for 2020, 2021 and 2022 by $-8.7 \%, 5.2 \%$, and $3.3 \%$, respectively. It implies that the Eurozone will increase its public debt ratio by about $6 \%$ on average for 2020 . However, the contraction of economy activities for some countries will be higher than the average because of detrimental impact of the Covid-19 pandemic, their weak public health systems, such as Spain and Italy, regarding core European Union health systems (Germany). Additionally, the results depend on any possible outbreaks of Covid-19 infections, as we should see after the end of the quarantine, the earlier implementation of a vaccine, the country's capacity of recovery based on healthcare implementation measures and other exogenous factors. It is also fair to point out that Eurozone economy activities have been showing some important recoveries since July 2020, some weeks after finishing quarantine and social immobilizations adopted since March, 2020.

Our econometric results have also confirmed the positive relationship between interest rate and public debt ratio; a one-point increase of interest rate increases also the public debt ratio by about $0.21-0.20 \%$. In the current context of low interest rates, this financial variable will not be the major determinant of the ratio increasing; however, we should pay especial attention in these current conditions to allow getting enormous indebtedness with very low interest rate. In the future, this situation can be reversed and increase the service cost of the public debt causing a stumble in Euro countries; especially, in the context of the board of the European Central Bank having increased the monetary stimulus (quantitative easing) and the volume of Pandemic Emergency Purchase Program (PEPP).

Let us remember, firstly, that the European Central Bank passed a PEPP for $€ 750$ billion (in the middle of March, 2020), to buy private and public sector debt securities up to the end of the year 2020. After that, it increased by $€ 600$ billion (starting June 2020) and has been extended up to June, 2021. In accordance with the European Central Bank, it has bought debt of $€ 33,058$ million. $€ 28,248$ is associated with the PEPP. By the end of the first half of 2020 , it has used $€ 15,508$ million, from the total $€ 1.35$ billion approved. Buying with the rest of the programs has reached $€ 4810$ million: $€ 2883$ million public debt and $€ 1927$ million in business debt. The European Central Bank also bought corporation bonds from 10 new businesses in the first half of 2020.

Our empirical model shows that a point increase in unemployment rate also increases the public debt ratio between $0.10 \%$ and $0.12 \%$. Therefore, after 2-3 months of obligated quarantines and generalized reduction of mobility, the unemployment rate has increased by about $10 \%$, which has also supported 
an increase in the public debt ratio, especially in the most damaged countries (Spain, Italy and France). Public spending on unemployment benefits is also expected to increase, e.g., ERTES and the minimum income implemented by Spanish government in March and June 2020, respectively, to mitigate the adverse effects and family income reduction caused by the pandemic.

Furthermore, later, the Spanish Minister of Labor announced the revision of ERTES legislation to improve it, in favor of weak and unemployed workers. Consequently, Spain will be the new HIDC in accordance with our operational definition, with public debt ratio of over $100 \%$ for the forthcoming years. Spanish public debt has increased by around $€ 22,500$ million in March, 2020, reaching $98 \%$ of the GDP; later it surpassed the $100 \%$, by the end of the first half-year 2020 . It is projected to reach about $115 \%$ of the GDP, by the end of the year 2020 .

In the case of Italy, after the public debt ratio reached $134.8 \%$ in 2019 , the second highest in the European Union, it has soared around $158.9 \%$ after the current pandemic, in the first half of 2020, and it will hit almost $160 \%$ by the end of 2020 . This will be the highest rate since World War II. It is expected to decrease slightly for 2021, if the Covid-19 pandemic will not see another outbreak. These estimations also have originated because of the predicted shrinking of the economy of about 10-12\% for 2020, regarding the last year. The European Union has made these predictions, highlighting the longer-term impact of coronavirus lockdown measures on the Eurozone states worst hit by the epidemic.

In the case of France, the second biggest Eurozone country, its economy will be shrunk severely due to Covid-19. Up to May 2020, less than a third of its working capacity was being used. In the first quarter of 2020, its economy contracted by nearly $5.8 \%$, from the previous three months. It is projected that the GDP will shrink by 10-12\% for 2020, which in turn will lead abruptly to an increase in its public debt ratio, reaching $115 \%$ of GDP by the end of 2020, after finishing at $98 \%$ the previous year (2019). The French government has estimated a package cost of $€ 100$ billion because of Covid-19.

Unfortunately, the contraction of the Spanish economy for the second quarter of 2020 reached $18.5 \%$. France's contraction in the same period was $13.8 \%$, the Italian contraction was $12.4 \%$; and in the case of Germany, 10.1\%. Lesser economies such as Portugal shrank by $16.5 \%$ in the same period. On average, the Eurozone economy is expected to shrink by more than $12 \%$ in the second quarter of 2020. Up to the first half of 2020, the Spanish economy shrank by about $22.1 \%$, as the most damaged Euro country. These results led to the poor recovery of employment in the Eurozone in accordance with official statistics of July 2020. This reduction of hiring new workers has also been caused by the digitalization of economy activities, such as e-commerce, e-government, remote jobs, online applications, etc. Up to June 2020 the Euro area's seasonal unemployment rate reached $7.8 \%$.

Regarding the life expectancy at birth, the short-run flexibility obtained is positive as we expected (see Table 6), about half-percent point, which in turn, with one more year of life expectancy, contributes to increasing the ratio up to a fourth-point percent in the Eurozone. A high public debt ratio can also result from poor institutional and governance indicators. For instance, the flexibility of the public debt ratio regarding government effectiveness has been -0.12 ; consequently, an improvement of this indicator by one point can help to slightly reduce the public debt ratio. Therefore, it could be recommendable to make different arrangements in the public sector to improve the effectiveness of the government.

As we expected, in our model, the relationship of public debt ratio with the lagged primary balance (PDeficit(-1)) result is negative, which means that a deficit will also increase the studied ratio. In this vein, different financial support (subsidies) have been introduced to help keep alive some industries, such as touristic and automobile industries, adopted by the Spanish government and other European countries, with the aim to help recover these industries, which is going to increase the primary deficit to such an extent that in accordance with European Central Bank it would affect the public debt ratio up to $115-120 \%$. Depending on economy recovery and also some outbreaks of Covid-19 that force some cities to return to confinement.

However, in the current pandemic and with its adverse effects, some Euro economies have been registering a deflation of the consumer prices index, due to the fact that international oil prices have reduced. This has been caused by quarantines of more than two months in different European 
and industrialized countries, and consequently by their industrial contraction. Furthermore, because of maximum reduction of people's mobility and transportation dictated by medical and scientific specialists, different kinds of vehicles (for earth, air and maritime transportation) did not consume any oil. This can help to increase the public debt ratio, in accordance with the expected relationship between the consumer price index and the public debt ratio (Table 4).

Finally, one of the last measures adopted in the Special European Council, 17-21 July 2020 [42], passed a Covid-19 pandemic recovery package and the budget for 2021-2027 for the 27 European countries, including the Eurozone. This is after the Commission presented, at the end of May, a very wide-ranging package combining the future Multiannual Financial Framework (MFF) and a specific recovery effort under Next Generation EU (NGEU). Undoubtedly, this could be a clear signal to move toward the necessary "fiscal union". Furthermore, the compromised green, digital and social public policies should be adopted in order to receive financial support, including the 19 Eurozone countries. The fund will help to finance the green and digital transition in European Union, computing, artificial intelligence and cybersecurity. The future public finance articles and working papers should also be concentrated on its sustainability after the Covid-19 pandemic.

\section{Conclusions}

To assess the evolution of the Eurozone public debts, we have identified three groups of explanatory variables: financial, social and institutional. The overall impacts seem to be in accordance with what was expected, and also according to economic theories. However, different variables we tested were not significant. We have interpreted this coherent modeling as evidence showing that, apparently, on average the public debt ratios have been sustainable before starting the Covid-19 pandemic, we found the expected relationships.

However, it is recommended to assess sustainability amid Covid-19 pandemic context that leads to an abrupt increase in the public debt ratios of Euro countries; especially, Spain, Italy and France, the most damaged countries, in accordance with different projections (such as those by the European Central Bank and International Monetary Fund). They were the most affected early on, adopting drastic policies such as strict quarantines, stopping their touristic activities by closing international borders, drastically reducing mobility, industrial activities and transportation services.

It is very important to reform pension systems, not only by implementing more homogeneous ones, but also more sustainable ones in accordance with the continuous increase of life expectancy at birth and market mechanisms. The positive relationship between this indicator and the public debt ratio is clear, positive and significant in different econometric models. After establishing a personal capitalized pension account (individually funded), some countries decided to privatize their pension system, such as some Latin American countries have done. Others have fixed a minimum government-backed pension for retired workers to promote the private participation of pension funds management. Furthermore, governance or institutional factors are also relevant in explaining the evolution of the public debt ratio.

High public debt ratio makes Euro governments very vulnerable to exogenous adverse shocks. These shocks include future drops in terms of trade, increases in the international interest rate, new pandemics, outbreaks of the current Covid-19 pandemic, etc., and may even cause a public debt financial crisis again. We know that international markets are susceptible to government over-indebtedness because of the Eurozone sovereign debt crisis in the 2000s, experiences of the Southeast Asia crisis in the 1990s and the Latin American debt crisis of the 1980s, which suffered compelling GDP contractions of two digits.

In the context of a new (re-negotiated) Maastricht Treaty, it is important to re-think the setting of new quantitative and qualitative public finance parameters to be achieved, within the public debt risk management for the next years, otherwise it would be unsustainability increased, to such an extent that future European generations would be condemned to pay, restricting future economic development. European citizens cannot be paying high debt services, it is time to really embark on a 
responsible policy of renegotiation, restructuring and debt forgiveness, taking into account the region's poor macroeconomic situation amid the Covid-19 pandemic, at least in the short and medium terms.

Author Contributions: This work is part of the research of H.R.B., supervised by J.P. Therefore, the former is the author of the results and the first draft of the paper. This draft was reviewed and edited by all co-authors, who provided ideas, discussion, and approved the final manuscript. All authors have read and agreed to the published version of the manuscript.

Funding: This research was funded by the Instituto Multidisciplinar de Empresa (IME) of the University of Salamanca and the Junta de Castilla and León [SA049G19].

Acknowledgments: Hernán Ricardo Briceño is grateful to Fundación Carolina, which has supported his stay at the University of Salamanca, Spain, with a scholarship. Both authors gratefully acknowledge the financial support by the Instituto Multidisciplinar de Empresa (IME) and the sound comments by three anonymous reviewers.

Conflicts of Interest: The authors declare no conflict of interest.

\section{Appendix A}

Table A1. Public Debt Ratio-Coefficient of Variation.

\begin{tabular}{cccccc}
\hline Countries & $\mathbf{1 9 9 5 - 1 9 9 9}$ & $\mathbf{2 0 0 0 - 2 0 0 4}$ & $\mathbf{2 0 0 5 - 2 0 0 9}$ & $\mathbf{2 0 1 0 - 2 0 1 4}$ & $\mathbf{2 0 1 5 - 2 0 1 9}$ \\
\hline Austria & $3.529 \%$ & $0.980 \%$ & $8.255 \%$ & $1.256 \%$ & $7.765 \%$ \\
Belgium & $5.361 \%$ & $4.849 \%$ & $5.082 \%$ & $2.434 \%$ & $2.834 \%$ \\
Cyprus & $5.915 \%$ & $6.531 \%$ & $12.182 \%$ & $28.645 \%$ & $5.597 \%$ \\
Estonia & $11.714 \%$ & $7.137 \%$ & $26.971 \%$ & $25.063 \%$ & $8.388 \%$ \\
Finland & $10.023 \%$ & $2.790 \%$ & $10.405 \%$ & $10.249 \%$ & $3.202 \%$ \\
France & $3.659 \%$ & $5.546 \%$ & $11.093 \%$ & $4.369 \%$ & $1.166 \%$ \\
Germany & $3.543 \%$ & $4.925 \%$ & $5.088 \%$ & $3.228 \%$ & $7.776 \%$ \\
Greece & $3.114 \%$ & $2.045 \%$ & $8.834 \%$ & $8.294 \%$ & $1.254 \%$ \\
Ireland & $15.967 \%$ & $10.578 \%$ & $49.824 \%$ & $13.068 \%$ & $10.821 \%$ \\
Italy & $2.390 \%$ & $1.745 \%$ & $4.585 \%$ & $5.778 \%$ & $0.301 \%$ \\
Latvia & $16.949 \%$ & $7.395 \%$ & $79.071 \%$ & $6.963 \%$ & $4.457 \%$ \\
Lithuania & $26.806 \%$ & $9.218 \%$ & $29.422 \%$ & $4.578 \%$ & $8.763 \%$ \\
Luxembourg & $7.987 \%$ & $2.701 \%$ & $39.144 \%$ & $8.922 \%$ & $4.356 \%$ \\
Malta & $23.852 \%$ & $6.717 \%$ & $5.137 \%$ & $3.716 \%$ & $12.590 \%$ \\
Netherlands & $9.110 \%$ & $2.460 \%$ & $11.931 \%$ & $5.988 \%$ & $11.657 \%$ \\
Portugal & $6.195 \%$ & $8.482 \%$ & $8.519 \%$ & $11.620 \%$ & $4.724 \%$ \\
Slovakia & $28.335 \%$ & $9.167 \%$ & $9.912 \%$ & $12.830 \%$ & $3.462 \%$ \\
Slovenia & $9.616 \%$ & $2.023 \%$ & $19.254 \%$ & $30.888 \%$ & $8.781 \%$ \\
Spain & $3.050 \%$ & $9.700 \%$ & $16.092 \%$ & $21.035 \%$ & $1.609 \%$ \\
\hline
\end{tabular}

Source: European Central Bank

\section{References}

1. Available online: https://www.imf.org/external/index.htm (accessed on 1 July 2020).

2. Malthus, R. An Essay on the Principle of Population; Johnson, J., Ed.; St. Paul's Church-Yard: London, UK, 1798.

3. Eatock, D. European Union Pension System; European Parliamentary Research Service: Brussels, Belgium, 2015; PE571.327.

4. Ghebreyesus, T. In Proceedings of the Seventy-Third World Health Assembly, Geneva, Switzerland, 18-19 May 2020.

5. Friedman, M. There's No Such Thing as A Free Lunch; Essay of Public Policy, Ed.; Open Court Publishing: Chicago, IL, USA, 1975.

6. Cossia, M. Asymmetric paths of public debts and of general government deficits across countries within and outside the European monetary unification and economic policy of debt dissolution. J. Econ. Asymmetries 2017, 15, 17-31.

7. OECD/EU. Health at A Glance: Europe 2018: State of Health in the EU Cycle; OECD Publishing: Paris, France, 2018. [CrossRef]

8. Allianz Research. Allianz Pension Report; Allianz and Euler Hermes: Munich, Germany; Paris, France, 2020. 
9. Lojsch, D.; Rodriguez-Vives, M.; Slavik, M. The Size and Composition of Government Debt in the Euro Area; European Central Bank-Eurosystem: Frankfurt, Germany, October 2011; Occasional Paper Series No. 132.

10. Wyplosz, C. Debt Sustainability Assessment: The IMF Approach and Alternatives; Graduate Institute of International Studies: Geneva, Switzerland, 2005.

11. Collignon, S. Fiscal Policy Rules and the Sustainability of Public Debt in Europe. Int. Econ. Rev. 2012, 53, 539-567. [CrossRef]

12. D'Erasmo, P.; Mendoza, E.; Zhang, J. What is a Sustainable Public Debt? Working Paper 21574; National Bureau Economic Research: Cambridge, UK; New York, NY, USA, 2015.

13. Kudła, J. Determinants of Public Indebtedness in European Union Countries, e-Finance: Financial Internet Quarterly; University of Information Technology and Management: Rzeszów, Poland, 2018; Volume 14, pp. 76-86. [CrossRef]

14. Aldama, P.; Creel, J. Fiscal policy in the US: Sustainable after all? Econ. Model. 2019, 81, 471-479. [CrossRef]

15. Barro, R.J. The Ricardian Approach to Budget Deficits; Working paper No. 2685; National Bureau of Economic Research: Cambridge, UK; New York, NY, USA, 1998.

16. Cooray, A.; Dzhumashev, R.; Schneider, F. How Does Corruption Affect Public Debt? An Empirical Analysis? World Development Elsevier: Spain, 2017; Volume 90, pp. 115-127.

17. Lee, I. Is Social Expenditure Responsible for Recent Rise in Public Debt in OECD Countries? Appl. Econ. Lett. 2018, 25, 43-46. [CrossRef]

18. Liu, Z.; Lyu, J. Public debt and economic growth: Threshold effect and its influence factors. Appl. Econ. Lett. 2020, 1-5. [CrossRef]

19. Available online: https://www.ecb.europa.eu/home/html/index.en.html (accessed on 1 July 2020).

20. Henningsen, D.M. The Origins of the Italian Sovereign Debt Crisis; Claremont McKenna College: Claremont, CA, USA, 2012; Senior Theses. Paper 379; Available online: http://scholarship.claremont.edu/cmc_theses/379 (accessed on 1 July 2020).

21. World Bank Database. Available online: https://data.worldbank.org/ (accessed on 1 July 2020).

22. Escolano, J. A Practical Guide to Public Debt Dynamics, Fiscal Sustainability, and Cyclical Adjustment of Budgetary Aggregates; Fiscal Affairs Department, International Monetary Fund: Washington, DC, USA, 2010.

23. Hansen, R.; Gordon, J. Deficits, Democracy, and Demographics: Europe's Three Crisis. West Eur. Politics 2014, 37, 1199-1222. [CrossRef]

24. Source Organization: (1) United Nations Population Division. World Population Prospects: 2019 Revision, or Derived from Male and Female Life Expectancy at Birth from Sources Such as: (2) Census Reports and Other Statistical Publications from National Statistical Offices, (3) Eurostat: Demographic Statistics, (4) United Nations Statistical Division. Population and Vital Statistics Report (various years), (5) U.S. Census Bureau: International Database, and (6) Secretariat of the Pacific Community: Statistics and Demography Program. Available online: https://data.worldbank.org/indicator/SP.DYN.LE00.IN (accessed on 1 July 2020).

25. Eurostat Database. Available online: https://ec.europa.eu/eurostat/data/database (accessed on 1 July 2020).

26. Available online: https://info.worldbank.org/governance/wgi/ (accessed on 1 July 2020).

27. Available online: https://www.transparency.org/en/ (accessed on 1 July 2020).

28. Goetz, A.M.; Jenkins, R. Voice, Accountability and Human Development: The Emergence of a New Agenda; Human Development Report 2002; United Nations Development Program: New York, NY, USA, 2002.

29. Tarek, B.; Ahmed, Z. Governance and Public Debt Accumulation: Quantitative Analysis in MENA countries. Econ. Anal. Policy 2013, 56,1-13. [CrossRef]

30. Ake, C. A Definition of Political Stability. Comp. Politics 1975, 7, 271-283. [CrossRef]

31. García-Sanchez, I.M.; Cuadrado-Ballesteros, B.; Frias-Aceituno, J. Determinants of Government Effectiveness. Int. J. Public Adm. 2013, 36, 567-577. [CrossRef]

32. Valcke, Anthony. The Rule of Law: Its Origins and Meanings (A Short Guide for Practitioners); SSRN: 2012; Available online: http://ssrn.com/abstract=2042336 (accessed on 1 July 2020).

33. Chalk, N.; Hemming, R. Assessing Fiscal Sustainability in Theory and Practice; International Monetary Fund: Washington, DC, USA, 2000; Working Paper. WP/00/81.

34. Ullah, S.; Akhtar, P.; Zaefarian, G. Dealing with endogeneity bias: The generalized method of moments for panel data. Ind. Mark. Manag. 2018, 71, 69-78. [CrossRef]

35. Roodman, D. How to do xtabond2: An introduction to difference and system GMM in Stata. Stata J. 2009, 9, 86-136. [CrossRef] 
36. Arellano, M.; Bover, O. La Econometría de Datos de Panel. Investig. Económ. 1990, 14, 3-45.

37. Blundell, R.; Bond, S. Initial conditions and moment restrictions in dynamic panel data models. J. Econom. 1998, 87, 115-143. [CrossRef]

38. Pindado, J.; Ignacio, R. Panel Data: A Methodology for Model Specification and Testing. In Wiley Encyclopedia of Management; Wiley: Hoboken, NJ, USA, 2014.

39. Beblavý, M.; Marconi, G.; Maselli, I. A European Unemployment Benefit Scheme; European Commission: Brussels, Belgium, 2017.

40. Kim, E.; Ha, Y.; Kim, S. Public Debt Corruption and Sustainable Economic Growth. Sustainability 2017, 9, 433. [CrossRef]

41. Gujarati, D. Basic Econometrics. Chap. 9. In Dummy Variable Regression Model; Mc Graw Hill: New York, NY, USA, 2008.

42. Available online: https://www.consilium.europa.eu/en/meetings/european-council/2020/07/17-21/ (accessed on 1 July 2020).

(C) 2020 by the authors. Licensee MDPI, Basel, Switzerland. This article is an open access article distributed under the terms and conditions of the Creative Commons Attribution (CC BY) license (http://creativecommons.org/licenses/by/4.0/). 